

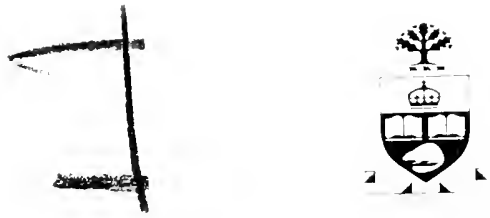

Prevented to the

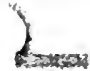

LIBRARY of the

UNIVERSITY OF TORONTO

fromil

the estute of

ANN BODDINGTON 


$$
-
$$


. 


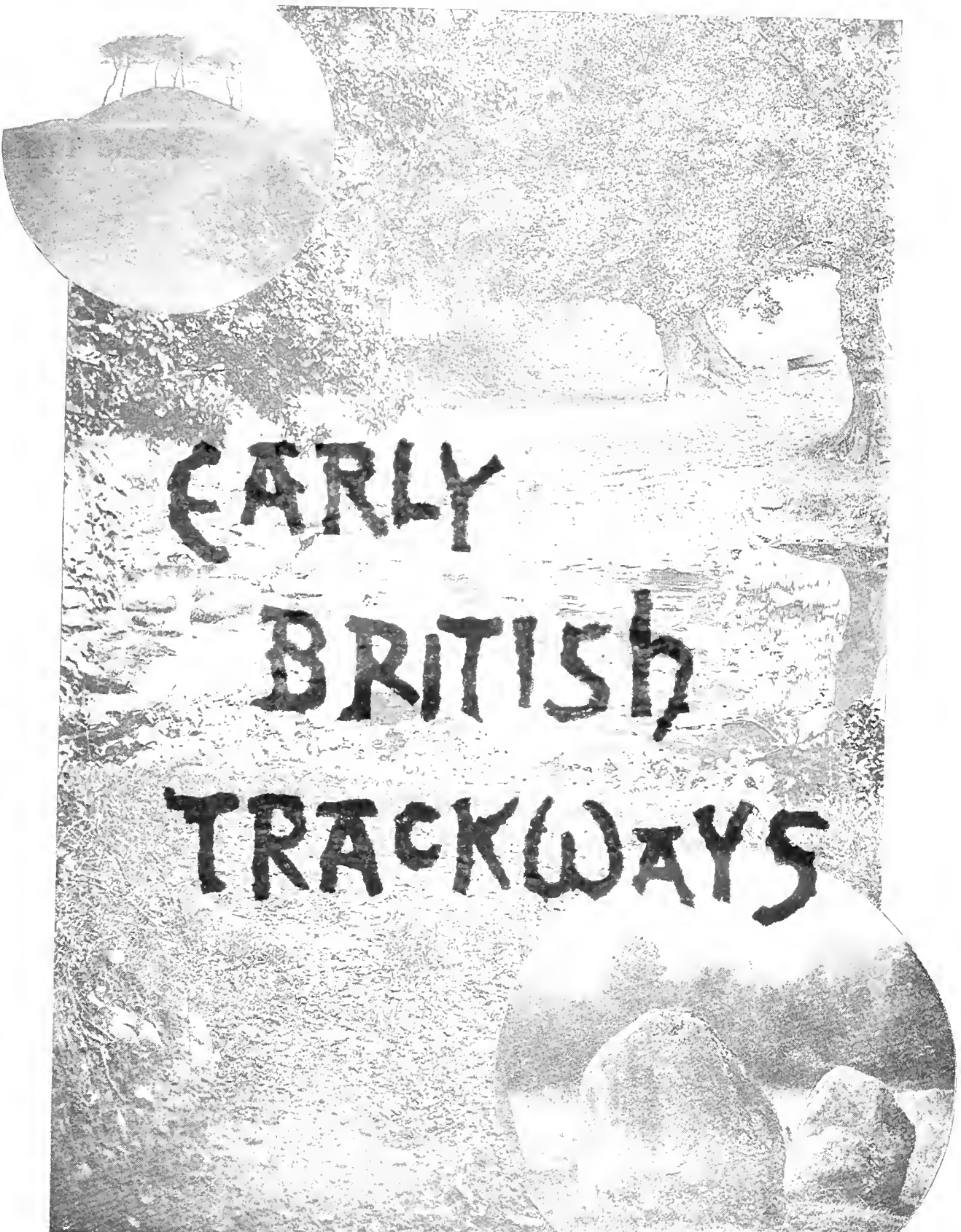

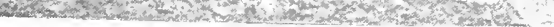





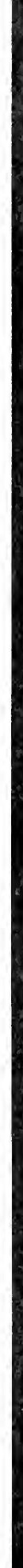


. 


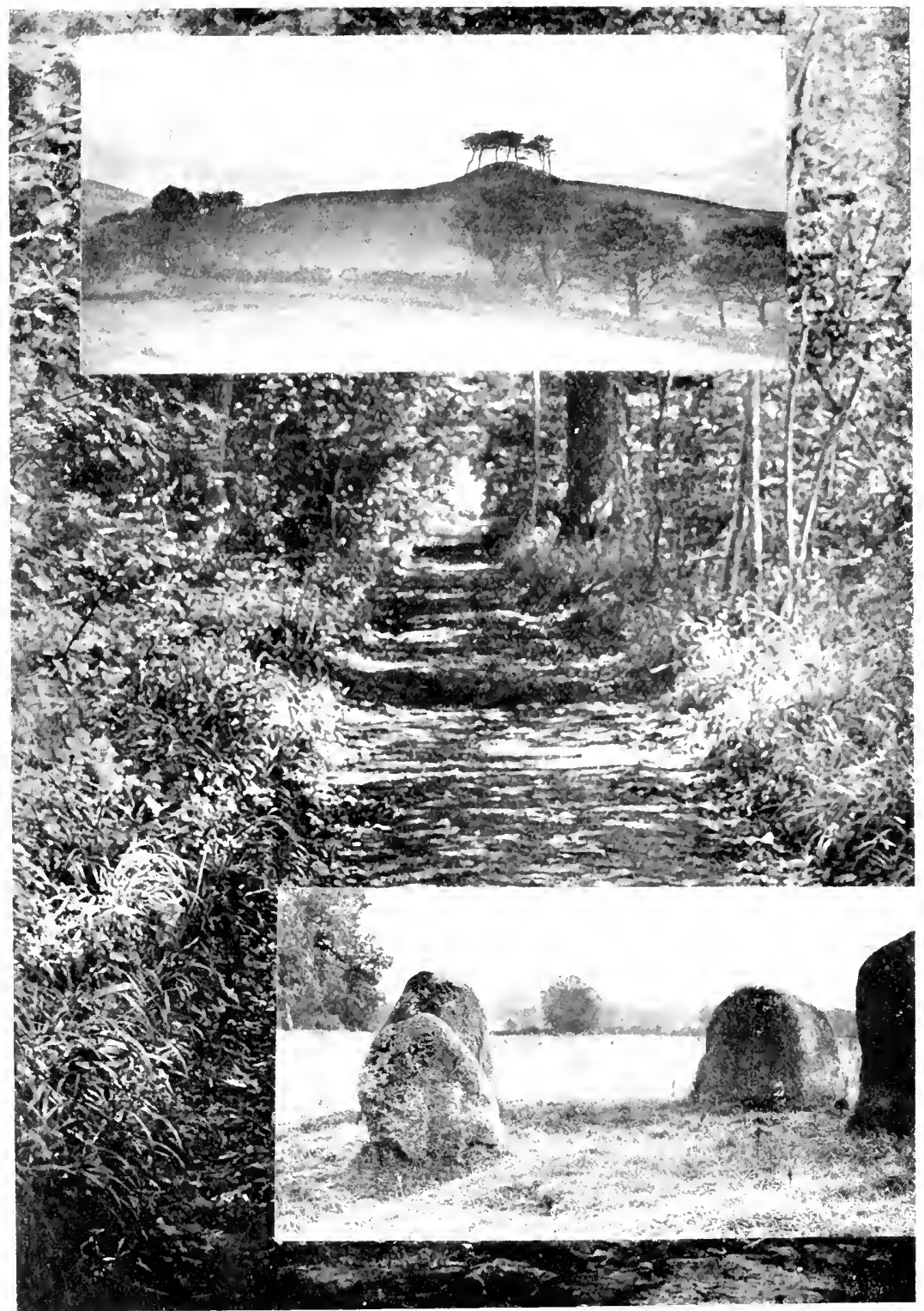

IRON[ISUEC

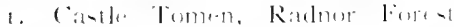

2. I l, ladd un at l,

3. Four Stume, Nis Rathor 


\section{Early British}

Trackways, Moats,

\section{Mounds, Camps,}

\section{and Sites.}

A Lecture given to the Woolhope Naturalists' Field Club, at Hereford, September, I92I, by ALFRED WATKINS, Fellow and Progress Medallist (for I9Io), of the Royal Photographic Society; Past President (I9I9) of the Woolhope Club. With illustrations by the Author, and much added matter.

I922:

HEREFoRd: THE WATKINS METER Co.

LONDON: SIMPKIN, MARSHALL, HAMILTON, KENT \& Co., LTD. 


\section{TABLE OF CONTENTS.}

Table of Illustrations Foreword

PAGE

INTRODUCTION

Odtline of Conclusions

Proof

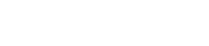

The Ley

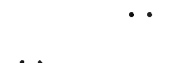

. 4

Antiquity of the Ley

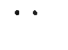

-

Individuality of a Ley

Mounds
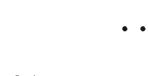

Earth-cuttings

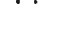

11

Water Srghting-Points

Mark-stones

Sighting Stones

Trees

Camps

Churches

Castles

'Traders' Roads

Hereford Trackways

Traditional Wells

Previous Data ..

Roman Roads

Place Names

Discovery by Place Name

THE Lisy-MeN

(a)

Hints to Ley-hunters

A Few Leys

$\sqrt{2}$

ENDWORD

INDEX

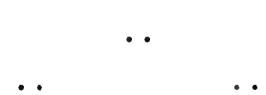

$\cdots$

15

15

16

17

19

20

21

22

22

23

24

25

26

26

30

30

31

33

34

35

ACKNOWLEDGMENTS

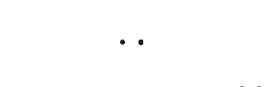




\section{TABLE OF ILLUSTRATIONS.}

FRONTISPIECE. Top. Castle Tomen, Radnor Forest, 1,250 feet above the sea, and is supposed to be the Cruger Castle of the Itinerary of Giraldus. Background. A glade on a ley. Bottom. The Four Stones, New Rarlnor, the easterly pair lined up for sighting over.

PLATE I. PRIMARY PEAK. Titterstone Clee Hill, and Park Hall, Bitterley.

PLATE II. MOUNDS. I, Tre-fedw, Pandy. The Skirrid, a primary peak, in distance. 2, Didley. With homestead alongside.

PLATE III. MOUND and MOAT. 1, Houghton Mound. 2, Lemore Moat. Note how slight is the dividing line between this type of mound and a moat.

PLATE IV. THREE-POINT PROOFS. 1 (a telephotograph), Hereford Cathedral and Pen-y-Beacon. Here the camera stood on a known ley in gateway near top of Hafod Hill, and the line runs through pond at foot (marked by sheet of paper), tower of Cathedral, and the 20 mile distant mountain point or bluff. Another ley is seen crossing the meadow in a straight line just where "the lowing herd winds slowly o'er the lea." 2, Tre-fedw Mound (see Plate II.), shown at top of sighting line down present road to ancient Monnow ford (alongside present bridge) at Llanvihangel Mill.

PLATE V. SIGHTING CUTTINGS (all telephotographs). 1, Notch with earthwork at Trewyn Camp above Pandy (Black Mountains). 2, Cutting through top of ridge at Marstow, a bridge now spans it, and the sighting line down to a ford on the Garron is indicated. The road beyond the cutting is on the ley. 3, Black Darren, Longtown (Black Mountains). This is taken from the Tan House, Longtown, and only 100 yards to right or left the notch hegins to lessen and then disappear.

PLATE VI. CAUSEWAYS. 1, Through pond near Ten Houses (now Priory Terrace), Holmer. Note the unmistakable direction, confirmed on map. 2, Through the River Monnow, behind Tan House, Longtown. A piece of fine engineering, the below-stream edge of large stones embedded in grouting or concrete. This ley is over the notch in Plate V. 
PLATE VII. CAUSEWAYS. 1, Over a ford of Olchon Brook, Longtown. 2, Ingestone, Ross. Through the "fold" and straight to the centre of the pond against the house. I cannot assign a period to any of these.

PLATE VIII. LEYS DISPLAYED. 1, Rhiw (mountain track) south of Llanthony Abbey, Mon. This is sighted for Balmawr on the ridge, and shows that where possible even mountain side tracks were kept straight. Taken in evening light and shows (on left) the triple tracks down which it is surmised the tile stones for roofing the Abbey to have been slid from the quarry on the top. 2, Stones at base of ancient Wye-side causeway at Bartonsham (formerly Bassam) Farm, Hereford City. The stones continue in a "wash-out" in bed of river to right, and the ley is sighted over tumps at Hoggs Mount and Holmer Lane. Note on bank to right the mark-stone for the ford (see Plate IX.).

PLATE IX. MARK-STONES. 1, Red Lion, Madley. On a "red line" ley from the Whitney pottery. Note subsequent boundary stone alongside. 2, Credenhill. 3, Wye Street, Hereford, marking the Palace Ford; there are a pair of these stones. Bartonsham Farm, Hereford (see Plate VIII.).

\section{PLATE $\mathrm{X}$. TRANSITION OF MARK-STONE TO CROSS.}

1, Wergin's Stone, Sutton. With flat face suited for sighting. A cavity for payments (or offerings) on the flat base. Early example of "shaft and base." 2, Pedlars Cross above Llanigon. A menhir chipped into rude semblance of a cross. 3, In churchyard, Vowchurch, unworked base. A ley runs through it. Inset, Sighting hole in shaft of Bitterley Cross. 4, In Capel-y-fin churchyard (Black Mountains).

PLATE XI. CHURCHYARD CROSS. Bitterley (see Inset Plate X.).

PLATE XII. TREE. Eastwood Oak, Tarrington, on a ley.

PLATE XIII. TREES. 1, A "One Tree Hill" near Llanvihangelnant-Melan. 2, Monnington Wallss, an avenue of Scotch Firs (Scots Pines) on a ley sighted on Scar Rock, Brobury, seen in distance. See Map, Plate XIX. 
PLATE XIV. CAMPS. I, Sutton Walls. One of the sighting mounds, there being four, a pair at eastern end, a pair at this the western end. 2, Herefordshire Beacon. Winds Point to the left.

PLATE XV. CHURCH. Church Lane, Ledbury. The detached tower of Ledbury Church is shown on the ley.

PLATE XVI. CASTLE. Wigmore Castle. The keep is on a sighting mound, the ley passing also through the church, as is almost invariable where castle and church are near together.

PLATE XVII. CASTLE. Brampton Bryan Castle (on a sighting mound) with Coxall Knoll, another mound, in the distance on the right.

PLATE XVIII. HOUSE IN MOAT. Gillow.

PLATE XIX. MAP. TWO LEYS. A, Consecutive strips containing the straight ley from Glascwm Hill to Birley Hill via four mounds ; Turret Tump, The Camp, Batch Twt, Almeley, Moat, Sarnesfield Coppice; and Weobley Church. B, Little Mountain to Holy Well Malvern, through Moccas "Castle" Tump, Preston-on-Wye Church, Byford Ford, Holmer Church, Palmer's Court, Moat, Shucknell, Walsopthorne. Portions of two interesting leys are also shown. c, Scar Rock, Brobury, through Monnington Walks to Monnington Church (see Plate XIII); and D, Little Mountain (Westbrook), through Arthur's Stone (dolmen), Cross End, Moccas Church, Monnington Church, St. Ann's Well, and Priory Church, Malvern.

PIATE XX. MAP. Portions of eight leys passing through Capel-y-tair-ywen (Chapel of the three yew trees), a chapel site, originally a mound, described in Woolhope Transactions, 1898 , p. 38 , on the high plateau below the great northern escarpment of the Black Mountains. A, Hay Tump (near church ford) to Pen-y-Beacon, on to Castle Tump, Rhos-goch. в, Mouse Castle to Tumpa, passes through Maes-coch (red field), Priory Wood, and the ancient "red" pottery, Whitney. c, Merbach to Llanelieu Church. D, Mynydd-brith Tump to Talgarth Church. E, Castle Tump, Dorstone, to Moat at Felin-fach. F, Snodhill Castle to Aberllynfi Gaer ; beyond Snodhill it passes to or through Holy Well, near Blakemere. G, Michaelchurch Escley to Llanigon Mound. H, Black Hill (Olchon) to Painscastle Mound. 


\section{FOREWORD.}

\section{To the Average Reader.}

I judge that you pick up this booklet with much the same ideas on the subject that I had a few months ago. The antiquarians had not helped you or me very much, but had left us with vague ideas and many notes of interrogation.

On early trackways they alternated between a misty appreciation of hill-tracks and ridgeways, and an implied depreciation of all trackmakers before the Romans came. To learn the meaning of mounds they did not go beyond the child's investigation of a drum, cut it open to see; and, if nothing was there, quite failed to profit by such valuable negative evidence. In perhaps one moat in five they found a dwelling, and argued finely on the defensive importance of a ring of water ; but as to the other four, with no dwelling, and in unexplained positions, they closed their eyes.

I do not know, dear reader, whether you will be as much astonished in reading the new facts which I disclose, and the deductions $I$ feel obliged to make, as I have been in the disclosure. Frankly, if another person told them to me, I should want to verify before acceptance. And I try to aid you to verify. But do note this-that the important point in this booklet is the previously undiscovered string of facts, which make it necessary to revise former conclusions. My deductions may be faulty. But the facts are physical ones, and anyone can test in their own district whether moats, mounds and churches do not line up in straight lines with a hill peak at one end, and with bits of old tracks and antiquarian objects on the line.

So please do not begin with the false--as being inapplicable-word "theory." I had no theory when, out of what appeared to be a tangle, I got hold of the one right end of this string of facts, and found to my amazement that it unwound in orderly fashion and complete logical sequence.

Make your own deductions when you have verified, and I have tried to help you. 


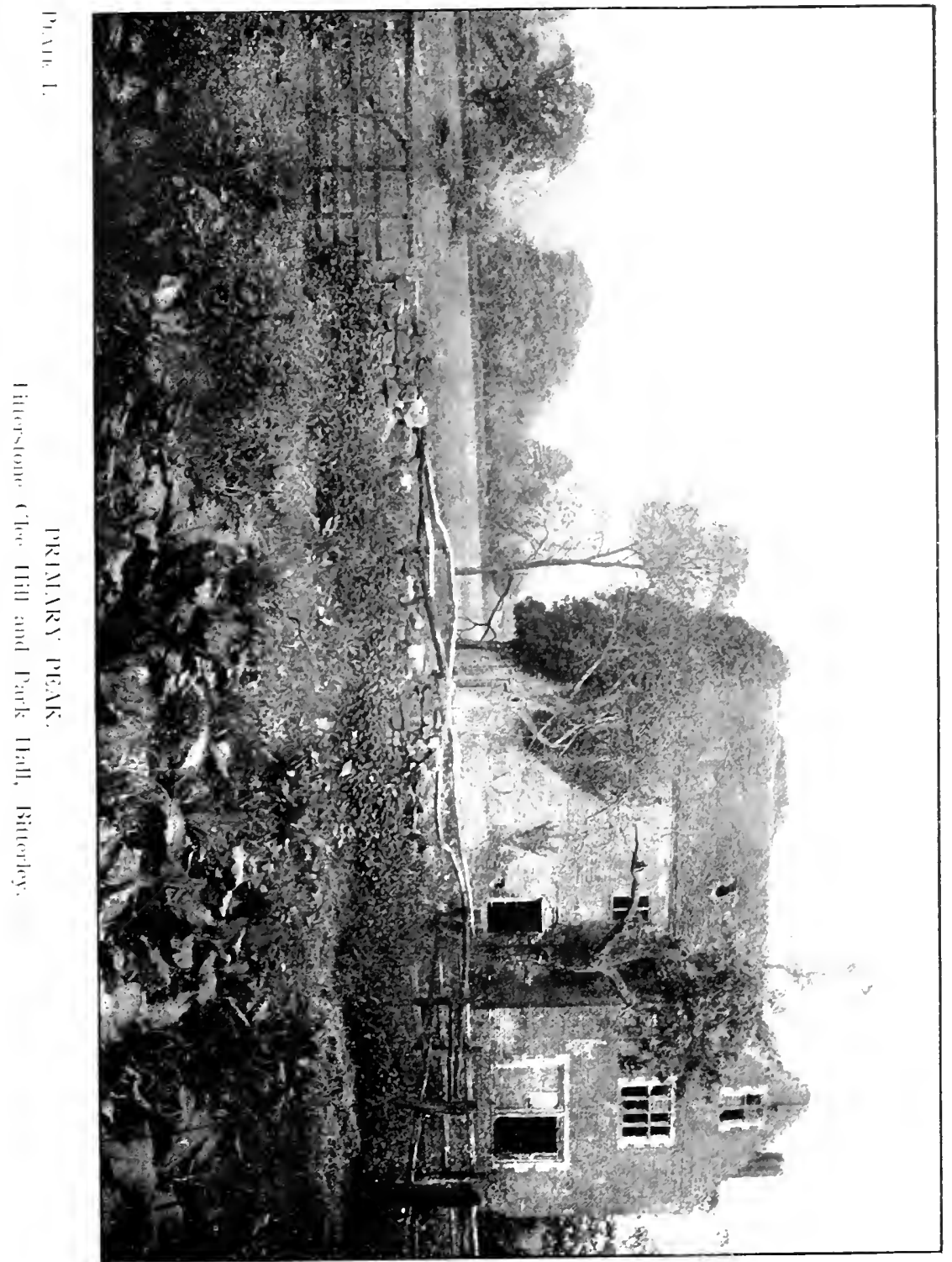



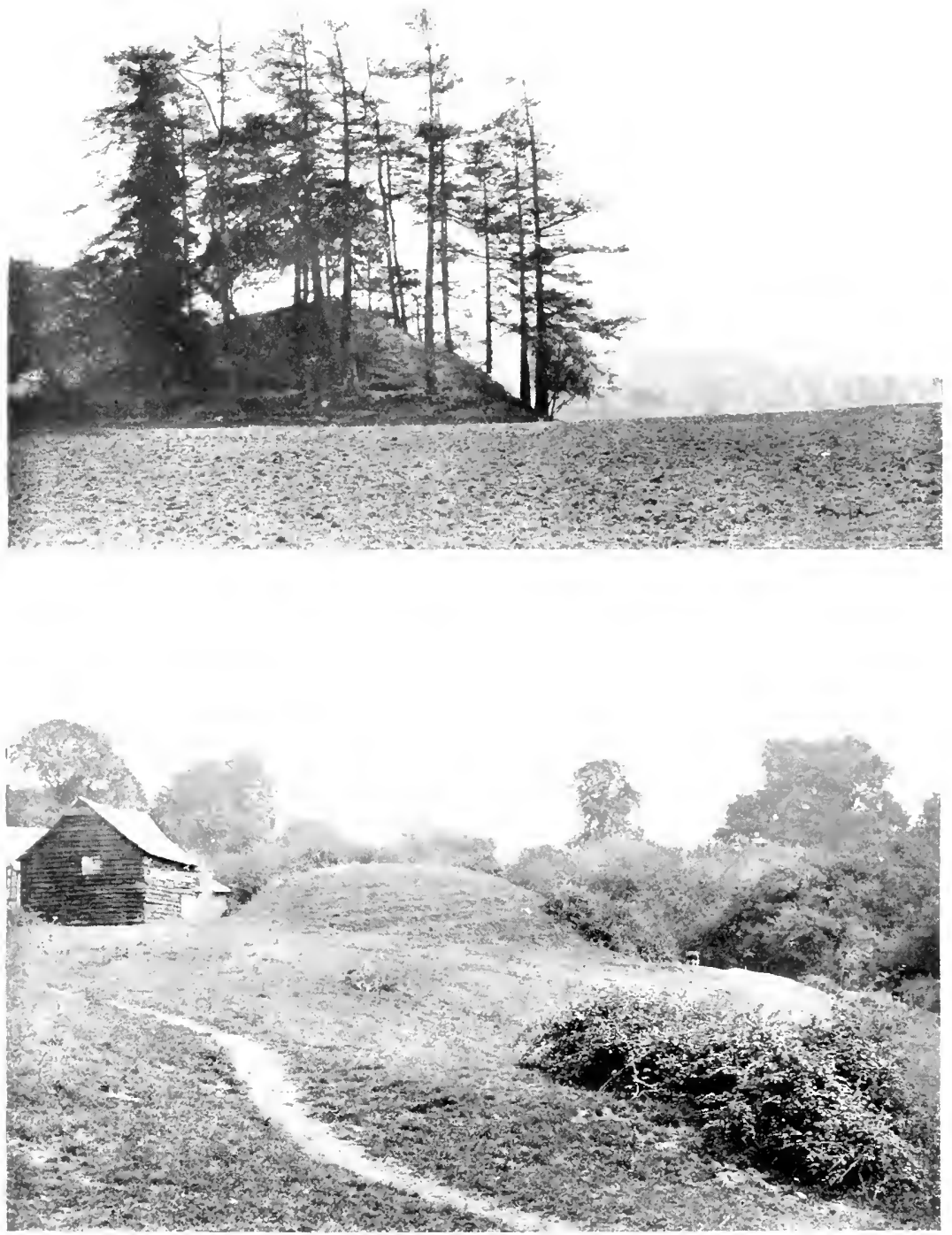

PIATE 11.

MOLNDS.

I. Trelidw, Pande Skirrid in Dintance

2. [)idley. 


\section{EARLY BRITISH TRACKWAYS.}

\section{MOATS, MOUNDS, CAMPS AND SITES.}

\section{IN'TRODUCTION.}

I have read of a lad who, idly probing a hill-side rabbit hole, saw a gleam of gold, then more, and in short had found a royal treasury. And he could not show all to those interested, but only samples, and he made mistakes in describing the dates and workmanship of the coins, vessels and jewels. But the treasure was there all the same.

I knew nothing on June 30th last of what I now communicate, and had no theories. A visit to Blackwardine led me to note on the map a straight line starting from Croft Ambury, lying on parts of Croft Lane past the Broad, over hill points, through Blackwardine, over Risbury Camp, and through the high ground at Stretton Grandison, where I surmise a Roman station. I followed up the clue of sighting from hill top, unhampered by other theories, found it yielding astounding results in all districts, the straight lines to my amazement passing over and over again through the same class of objects, which I soon found to be (or to have been) practical sighting points.

For the sake of clearness I will give an outline of the whole method before furnishing proofs and examples.

It is necessary first to clear the mind of present ideas of roads from town to town, or with enclosed hedges, also of any assumption that orderly road planning was introduced by the Romans, and that my paper is to explain the Roman roads.

Presume a primitive people, with few or no enclosures, wanting a few necessities (as salt, flint flakes, and, later on, metals) only to be had from a distance. The shortest way to such a distant point was a straight line, the human way of attaining a straight line is by sighting, and accordingly all these early trackways were straight, and laid out in much the same way that a marksman gets the back and fore sights of his rifle in line with the target. 


\section{OUTLINE OF CONCLUSIONS.}

During a long period, the limits of which remain to be discorered, but apparently from the Neolithic (later flint) age on past the Roman occupation into a period of decay, all trackways were in straight lines marked out by experts on a sighting system.

Such sighting lines were (in earlier examples) from natural mountain peak to mountain peak, usually not less than $1,000 \mathrm{ft}$., in this district, probably lower heights in flat districts, such points being terminals.

Such a sighting line (or ley) would be useless unless some further marking points on the lower ground between were made. Therefore secondary sighting points were made, easily to be seen by the ordinary user standing at the preceding sighting point, all being planned on one straight line. These secondary, and artificial, sighting points still remain in many cases, either as originally made, or modified to other uses, and a large number are marked on maps, and are the basis of my discovery.

They were constructed either of earth, water or stone, trces being also planted on the line. Sacred wells were sometimes terminals in the line, and sometimes included as secondary points.

Between the sighting points the trackway ran straight, except in cases of physical impossibility, but did not of necessity go as far as the primary hill tops.

Earth sighting points were chiefly on higher ground, and now bear the name of tump, tumulus, mound, twt, castle, bury, cairn, garn, tomen, low, barrow, knoll, knap, moat and camp. Another form of earth sighting point was in the form of a notch or cutting in a bank or mountain ridge which had to be crossed by the sighting line.

Water sighting points seem to have evolved from the excavations made for the tumps or moats. Almost all are on low ground, to form a point or ring of reflection from higher ground, and are now known as moats and ponds. blocks.

Stone sighting or marking points were natural (not dressed)

Sighting lines were (in earliest examples) up to 50 or 60 miles in length, later on rather shorter, down to a few miles.

Sighting points were used for commerce and for assemblies of the people. 

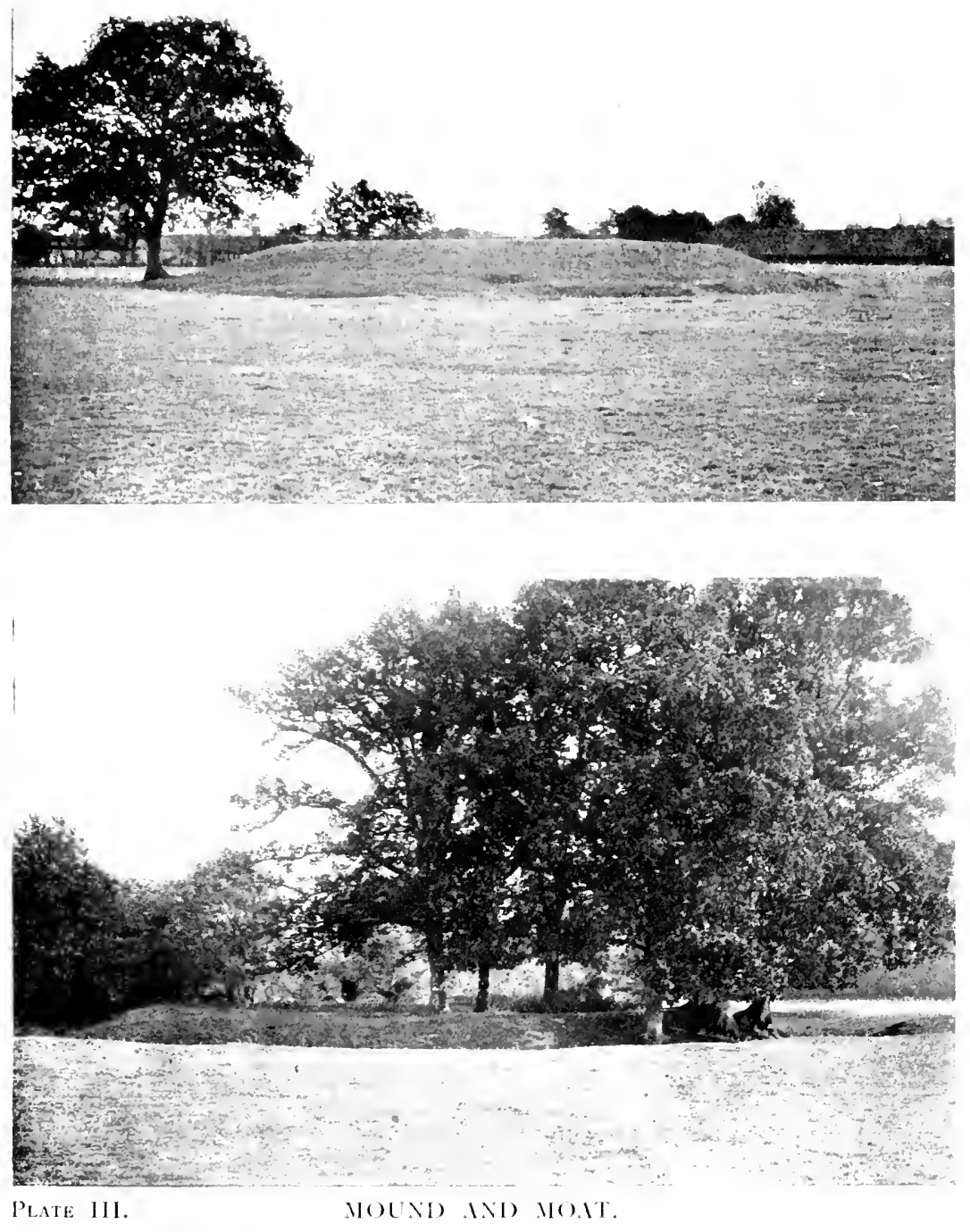

I. Houghton Mound.

2. Lemore Moat. 

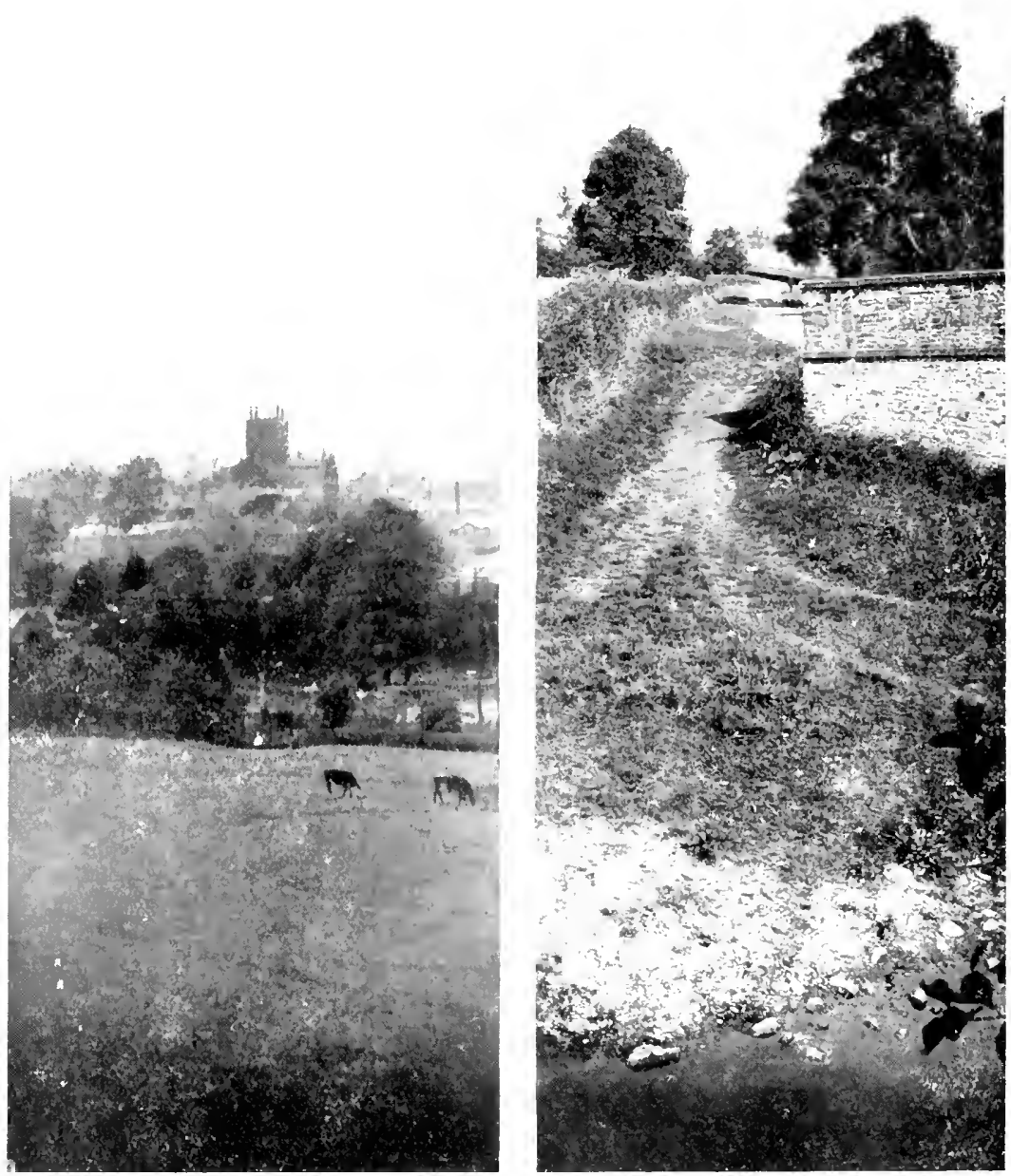

I'..11: IS.

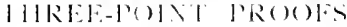

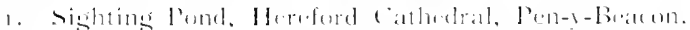

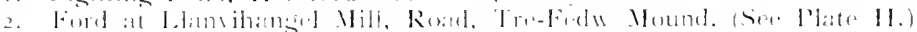


When troublesome times came and stronger defences wanted, the groups of two or three sighting tumps which came near together (especially on the top of a hill) often had defensive earthworks added to make a fortified enclosed camp.

These trackways of successive ages grew so thick on the ground as to vie in number with present day roads and by-ways.

All forms of sighting points became objects of interest, superstition, and genuine veneration, and as such were utilized on the introduction of Christianity.

Practically all ancient churches are on the site of these sighting points (tumps or stones), usually at a cross of tracks, and there is evidence that in some cases the churchyard cross is on the exact spot of the ancient sighting or marking stone.

In time, homesteads clustered round the sighting points, especially the ponds.

The moats and tumps were often adopted in after ages as sites for the defensive houses or castles of wealthy owners.

Hundreds of place names give support to these propositions.

\section{PROOF.}

The facts I have discovered, which lead up to the conclusions, can be verified for the most part on an inch to mile ordnance map with aid of a straight edge.

Taking all the earthworks mentioned, add to them all ancient churches, all moats and ponds, all castles (even castle farms), all wayside crosses, all cross roads or junctions which bear a place name, all ancient stones bearing a name, all traditional trees (such as gospel oaks), marked on maps, and all legendary wells. Make a small ring round each on a map. Stick a steel pin on the site of an undoubted sighting point, place a straight edge against it, and move it round until several (not less than four) of the objects named and marked come exactly in line.

You will then find on that line fragments here and there of ancient roads and footpaths, also small bits of modern roads conforming to it. Extend the line into adjoining maps, and you will find new sighting points on it, and it will usually terminate at both ends in a natural hill or mountain peak, or sometimes (in the later examples) in a legendary well or other objective.

If you travel along the actual sighting line you will find fragments of the road showing as a straight trench in untilled land, although 
these are few and far between, as the plough obliterates it all. The line usually crosses a river at a known ford or ferry. Sighting tumps not marked on the map are also to be found.

Two specific proofs are illustrated in Plate IV. and explained in the Table of Illustrations. Also from the highest point of the earthworks of Dinedor Camp the spire of All Saints' Church can be seen precisely between the pinnacles of Hereford Cathedral, thus showing a sighting tump and two churches on one ley. The Offa Street example (see under Churches) is another three-point proof.

\section{THE LEY.}

The sighting line was called the ley or lay. Numbers of farms and places on sighting lines bear this first name, viz., the Ley Farms, Weobley, Grafton, Stoke Edith, and many other places. Wyaston Leys, Monmouth, Tumpey Ley and Red Lay, near Letton, and Redley in Cusop parish.

There were cleverly planned high level mountain tracks which, although on an average sighting line, could not (being on the side of a mountain ridge) keep straight, but took a serpentine course, in round the cwms, and out round the headlands. But viewed edgeways they are a straight line (see Plate VIII.) as keeping a uniform level or slope. Such are found high on the Malvern ridge, the road (on three leys) through Oldcastle to Blaen Olchon, the lovely Bicknor Walks near Symonds Yat, the Precipice Walk near Dolgelly.

There are signs of parallel trackways quite close together, whether one to take the place of an older one I do not know. And between Malvern Wells and Hanley Swan are three symmetrical triangular woods (see Map, Plate XIX.), which I find indicate parallel roads, one-sixth mile apart, running northwards, and with a collecting road here at right angles, which comes over the ridge and through Mainstone Court. There are six of these equidistant parallel roads.

The fact of the ley is embedded in the rural mind. A country man in directing your path will invariably bring in the now misleading, but once correct, " keep straight on." It was once absolutely necessary to "keep straight on" in the ley, for if you did not you would be de-leyed on your journey. This is not said as a pun, but as in some succeeding sentences, to point out the place of the ley in the evolution of our language.

Where the ley laid in a wood became a glade (see Frontispiece). We came through one over Worsell Wood in a Club excursion on our way to Gladestree. Where the ley had lain for a time often became 
a lane. This last noun became a verb used in the 18 th century enclosure acts, where ground was "laned out." Where it was so laned out it became land. There is a Laynes Farm near Huntley. the land."

It is still a common phrase to go out to see "the lay (or lie) of

The trackways are chiefly 6 feet $6 \mathrm{in}$. to 9 feet wide. I illustrate two pitched causeways at Longtown, a fine one through the Monnow near the Tan House, and the other close to a ford over Olchon Brook (Plate VI.). Another through the farm yard at Ingestone (Ross) going to the centre of the sighting pond (Plate VII.).

\section{ANTIQUITY OF THE LEY.}

The word " ancient" covers a vast period. If-as I have proved - the tumps or burys are sighting tumps, excavations also prove that they usually date back to the Neolithic age, which, according to Mr. Ault's recent "Early Life in Britain," cannot be later than 2,000 B.C., and may be 4,000 B.C. A prehistoric trackway might, therefore, be planned and made more than three thousand years before the old Road (which is a route rather than a road) was devised or evolvedas Mr. Belloc so well describes-as a Pilgrim's Way from Winchester to Canterbury.

I have found that the persistent things down the ages are not the courses of the roads or tracks, but their sighting points, and that cross roads with a place name are such. Place names are also persistent, some of them going back to prehistoric times, but others evidently mediæval. But the real dating of the leys and when the system fell into decay is for future investigation.

\section{INDIVIDUALITY OF A LEY.}

Each ley or track was as separate and distinct from other leys as each animal or tree is an organism distinct from other animals or trees. As they crossed each other, no doubt users often transferred from one to the other at the crossing, and struck out in an altered direction, hence the place name element "turn." But the way thus travelled was a route, not a road. It is an absurdity to speak of a sighted road having branches, or bending. Each individual track was "a long lane that has no turning."

Previous writers, treating, say, of Roman or of mediæval roads, not knowing of the existence of the ley, assume that they are speaking of original primary structures, when they are only describing a route evolved from a number of the leys I describe, retaining the sighted structure in the case of Roman roads, but losing most of it by mediæral times. 
Many leys acquired in after ages individual names from the use they were put to, and such names were transferred to the sighting points.

I find in several cases a group of leys with sighting points passing quite close to, and taking no notice of, quite a distinct group of leys with other sighting points, the two sets being either of two different periods, or part of separate systems made by different sets of ley-men living in different districts.

A most surprising fact is the enormous number of leys.

\section{MOUNDS.}

The mounds whose many names I have mentioned are artificial. I do not question the fact that they were often used as burial mounds, and perhaps even built with that end in view; but the straight leys on which I find practically all in this district line up (in connection with other sighting points) prove their primary purpose to be sighting tumps. Arthur's Stone, a dolmen, which was probably the core of a burial tump, is on two sighting lines.

I find various stages of evolution of the tump. The small tump at a road junction for the local road construction, examples at Cross in Hand, Belmont, Hungerstone, Shelwick old Turnpike, near Bowley Town (called the Stocks). With most of these the pond from which the earth was dug adjoins. When much larger tumps were wanted the trench of earth to make them was dug in the form of a ring, and a moated tump resulted, as at Eardisland (with water), Pont Hendre, Longtown (dry). The water in these excavations proved to be splendid sighting points by reflection from higher ground, and the moats with no tump but a flat plateau within a ring of water evolved. Many tumps on banks, as at Tre-Fedw, near Pandy, show no excavations. Many tumps were at the junction of leys, showing the technical skill of the early surveyors, who must have mored a temporary sighting point on one ley until it fell in the line of a second ley. A sighting tump always commanded a fine, clear view in at least two directions, and in after ages was coveted as a dwelling spot. At Didley is an instance of the simple homestead against it. Thus sighting produced the sites, this being only one of many instances where the record of the ley is embedded in the English tongue. The generic name of Merry Hill applied (as near Hereford) to many tumps gives a clue to their use as assembly points for recreation, confirmed by folk lore and surviving customs of dancing in a circle with hands linked. The folk-mote was held at a tump with a dry moat, so admirably adapted for seating. 

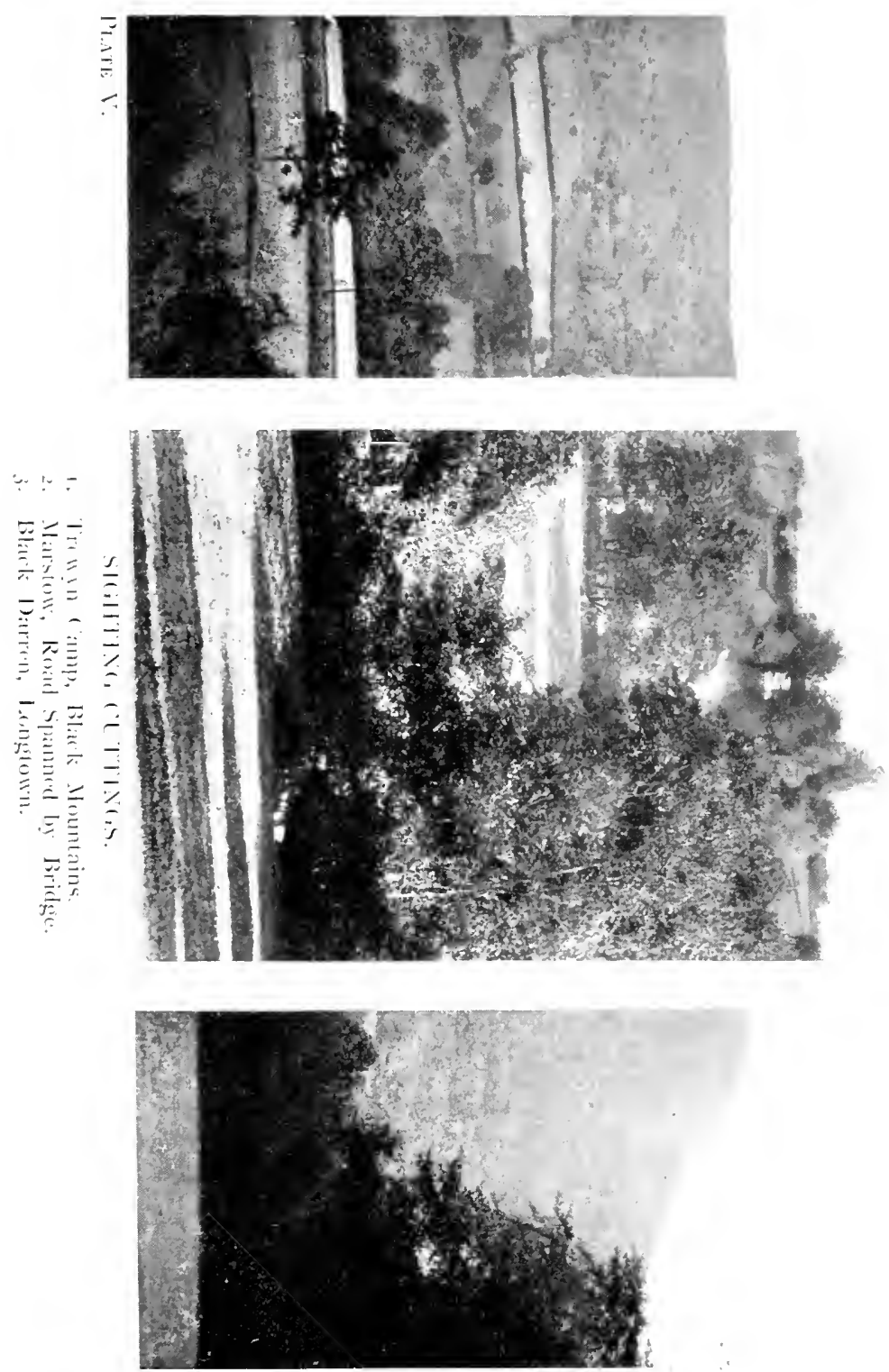

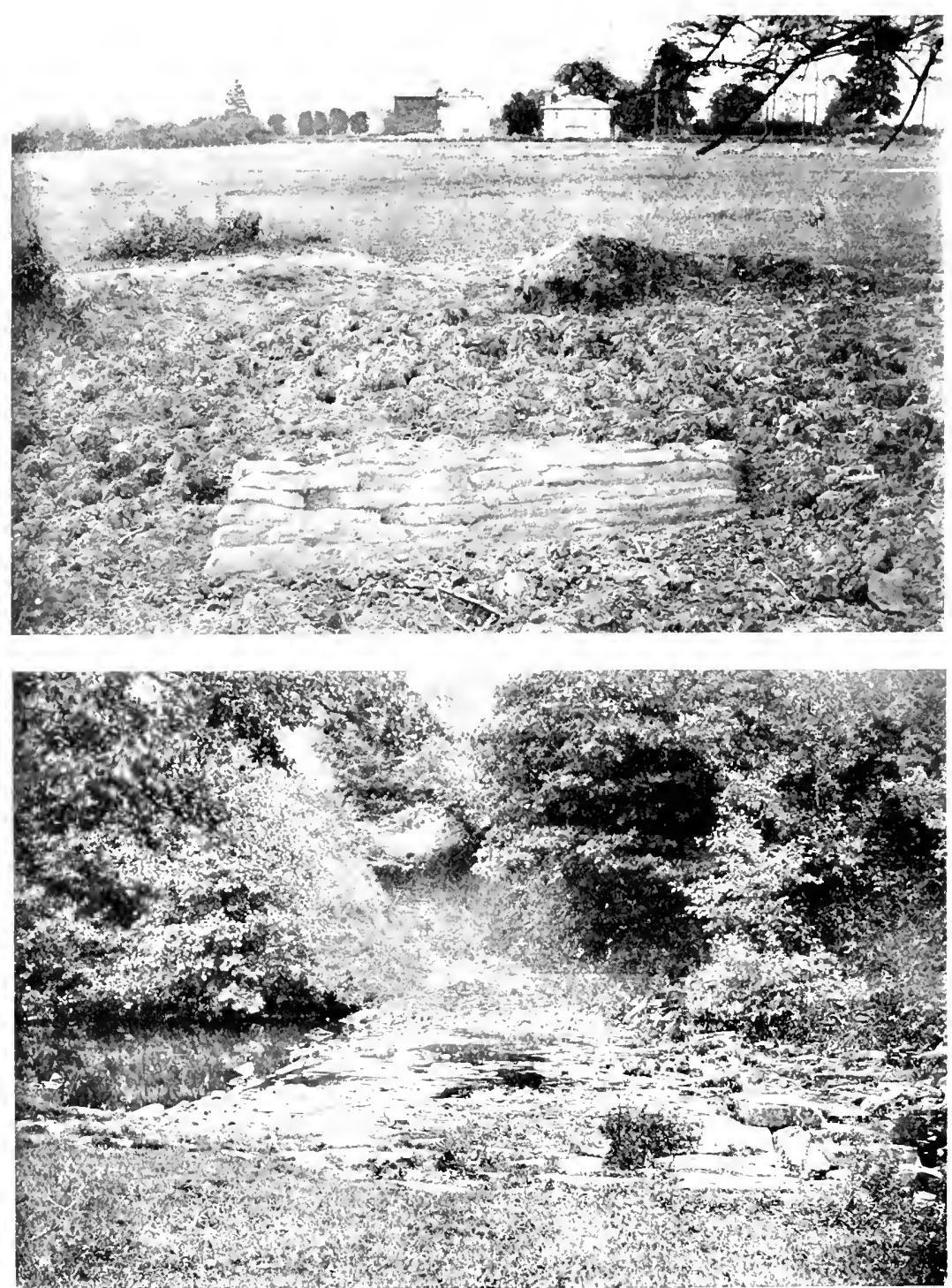

PIITE II.

C.MSIIISS

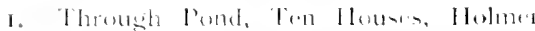

2. Through River Monnow, longtown. 


\section{EARTH CUTTINGS.}

Where a mountain ridge stood in the path of a ley, the surveyor, instead of building a tump on the ridge as a sighting point, often cut a trench at the right angle and in the path of the ley. This shows as a notch against the sky and makes a most efficient sighting point from below. I have counted eight such artinicial notches in the mountain ridge when on the road from Llanvihangel Crucorney to Longtown. Each notch can only be seen on the line of sight, and disappears when a quarter of a mile right or left. They are sometimes emphasised (as at Trewyn Camp) by an earth work thrown up on one side. The Wych on the Malvern ridge is an instance.

The two fine gaps near Flansford (Goodrich) and Marstow (Plate V.), both with bridges over them, are also ancient sighting cuttings.

The sighting cuttings were also used in passing over banks in lower ground. Cullis is one of the names for such an earth cutting, as Portcullis between Withington and Preston Wynne, and High Cullis above Gatley Park, recently visited by the Club.

There is a very neat example of such a cutting at Hungerstone, near Allensmore, where the cutting in the bank allows the ley to be sighted on to a pond on its way to the next tump, the one close to the church at Thruxton.

The word hunger (a common place-name element) indicates, I think, a cutting through a bank, not the bank itself, as now surmised. There are cuttings at most fords, which permit the water to be seen from above and serve as sighting points. The cutting near Charing Cross, which gives the name to the present Hungerford foot-bridge, probably came down through Inigo Jones' beautiful Water Gate.

Mr. Codrington in his book on Roman Roads describes the method used by Roman engineers "well known to surveyors for laying out a straight line between extreme points not visible from each other, from two or more intermediate points from which the extreme points are visible. By shifting the intermediate points alternately all are brought to lie in a straight line." This method was evidently used for all the leys.

\section{WATER SIGHTING POINTS.}

I have suggested how these might have developed from the tump, and shown where pond and tump were used together. Moats are a similar arrangement on a larger scale. The trackways go straight for the island part of the moat. It is not the least amazing part of 
this revelation that I find practically all the small horse or cattle ponds in field or homestead which are marked on a 6in. ordnance map have leys running through them, and that examination in dry seasons shows signs of the road passing through them. "And when we cleaned the pond out we found it cobbled at the bottom " is a frequent report made by a farmer. I show a photograph of one of these at Bridge Sollars, with the trench of the road beyond.

A beautifully constructed causeway of even pitched stones is to be seen at the foot of Holmer Hill (Plate VI.). It has well defined edges, and lics at the bottom of a small sighting pond. In the crevices of its stones I found fragments of crude red pottery, with a bit of early (Anglo-Saxon) ornament, a bit of iron slag, and a bit of iron. This ley is sighted on the North Hill, Malvern.

I cannot say that passengers walked through the bottom of these ponds (most of them have one shelving edge, with the opposite bank steep), but to this day an ancient road (at Harley Court, Hereford) does go through the bottom of a small pond, being sighted through the Cathedral.

When there is a large central island on a moat I surmise early dwelling houses-a subject for spade research. There evidently came a wish for roads not running through the water, and a pair of ponds or lakes with a causeway between, such as we find at Holmer fish ponds, is frequently found on the map, and is the sure indication of an ancient trackway. Probably the square moats are later than the circular ones. I saw in the grass the track of a 15-foot road (probably Roman construction) making straight for the centre of Yarkhill Moat.

Many ponds (as at Belmont, The Burcot, and adjoining Ledbury Churchyard) not known as moats are really such, their islands being sighting points.

The causeway to the centre of the moat evidently suggested their use (many ages after they were made) as a defensive ring of the house of a rich owner, as at Brinsop, Badesley Clinton, Gillow, ete.

I think that the word lake, now used for large sheets of water, was originally applied to small reflecting sighting ponds as well. The place names of Sutton Lakes, Withington Lakes, Letton Lakes, and Tumpy Lakes are explained by this theory.

MARK STONES.

'These (Plate IX.) were used to mark the way. They were of all sizes, from the Whetstone on Hargest Ridge to a small stone not 16 
much larger than a football. Some were long stones or menhirs, but few remain upright in this district. I know of three lying fallen on leys, namely on the wall at the south gate of Madley Churchyard, near the inn at Bush Bank (cross road from Weobley), and used as a bridge over a ditch near the Field Farm on the Litley-Carrots path.

I show photographs of a fine stone at Red Lion, Madley, having a flat top, and of the type which developed into market stones. The market stone at Grosmont Town Hall (on which the first market basket placed on market day paid no toll) is the successor of such a mark stone. Two marking stones (with ancient brick houses built partly on them) stand unnoticed in the short Wye Street, just over Wye Bridge at Hereford. They mark the Palace Ford, and a ley from Castle Hill to Hunderton. They are of the same peculiar stone (not "old red") as at Madley, Colwall, etc.

Wergin's Stone (Plate X.) is a late type of mark stone which was the prototype of the churchyard and wayside crosses, all of which I think are on the sites of original mark stones, as I find leys passing through them.

In studying such crosses, I was puzzled to find several (as at Vowchurch, Hentland, Capel-y-fin) with ancient rough unworked stones as a base. I am now certain that these bases are the original stones marking a ley. The Pedlar's Cross near Pen-y-lan Farm above Llanigon (mentioned in Miss Jacob's fine story, "The Sheep Stealers ") has been chipped into a rude suggestion of a cross without taking down, and a flat mark stone on which Archbishop Baldwin is said (by tradition) to have preached when on his tour with Giraldus in 1188, has had a cross inscribed on it. It stands close to St. Ishaw's Well at Partricio.

There is a striking marking stone on the Rhiw Wen route in the Black Mountains.

Other stones on leys are :-White Stone, Withington (with original stone at the base of an inverted fragment of its successora wayside cross); Queen Stone, Huntsham, at Credenhill cross-roads, at the foot of Froom's Hill, on the road near Turnaston Church, marking a ford at Bartonsham Farm, Hereford, and Crossways, Bollingham. The stone that all the Kings of England are crowned on is certainly a mark stone.

\section{SIGHTING STONES.}

Mark stones may be on one side of the track, as are the whitewashed stones which mark a coastguard's cliff walk to-day. But there also appear to have been sighting points of stone exactly on the ley, so constructed as to indicate its direction. 
The Four Stones near Harpton, New Radnor, are four upright boulders (see Frontispiece) in an irregular quadrangle, and no one has explained their purpose.

I took sighting lines over successive pairs of, stones, five lines being possible, and although the work on the map is not yet completed, I can definitely say that the "Four Stones" are directing posts which point out at least two leys, proved by passing through other good points. The first goes to the highest point in Deerfold Forest (The Camp, 940ft.) in one direction, and in the other through The Folly and on the main road at Llanvihangel-nant-Melan, over Bryn-y-Maen Hill, here appearing to strike another "four stones," and through Llansaintfraed in Elvel Church to some peak beyond.

The second ley starts from Bach Hill (one of the highest parts of the Radnor Forest); through the Four Stones, dead on main road through Walton village, dead on main road past Eccles Green, through Upperton Farm and Kenchester Church, and dead on the present road which is the S.W. boundary of the Roman station of Magna; then going over the Wye through Breinton Church.

Bitterley Churchyard Cross has a circular hole through its shaft at a convenient height for sighting. Mr. J. C. Mackay kindly had the exact direction of this taken for me by sighting compass. It is $28 \frac{1}{2}^{\circ}$ E. of Magnetic N., and this on the map exactly strikes Abdon Burf (or Barf), the high point (1,790ft.) of the Brown Clee. Southwards the line runs through Stoke Prior and Hope-under-Dinmore Churches, is confirmed in other ways, and goes over the Wye at Belmont House.

Bitterley Cross is of 14th century date ; it must be the successor of a sighting stone which in some way pointed the direction of the ley, and it suggests that sighting along a ley had not quite died out by the 14th century.

These two proved instances of sighting stones, together with the cases of stonc rows on Dartmoor, and sighting columns on Sutton Walls, will give the clue to the hitherto unknown purpose of many important ancient stone monuments.

It is probable that the flat face of a mark stone, as in Wergin's Stone (Plate X.), pointed out a ley. There is a Dial Post near Tewkesbury which, with the Dial Carreg near Cwm-yoy, seems to denote the above purpose, and the last stone is an upright shaft of rectilinear shape like the supposed cross at Capel-y-fin (Plate X.). 


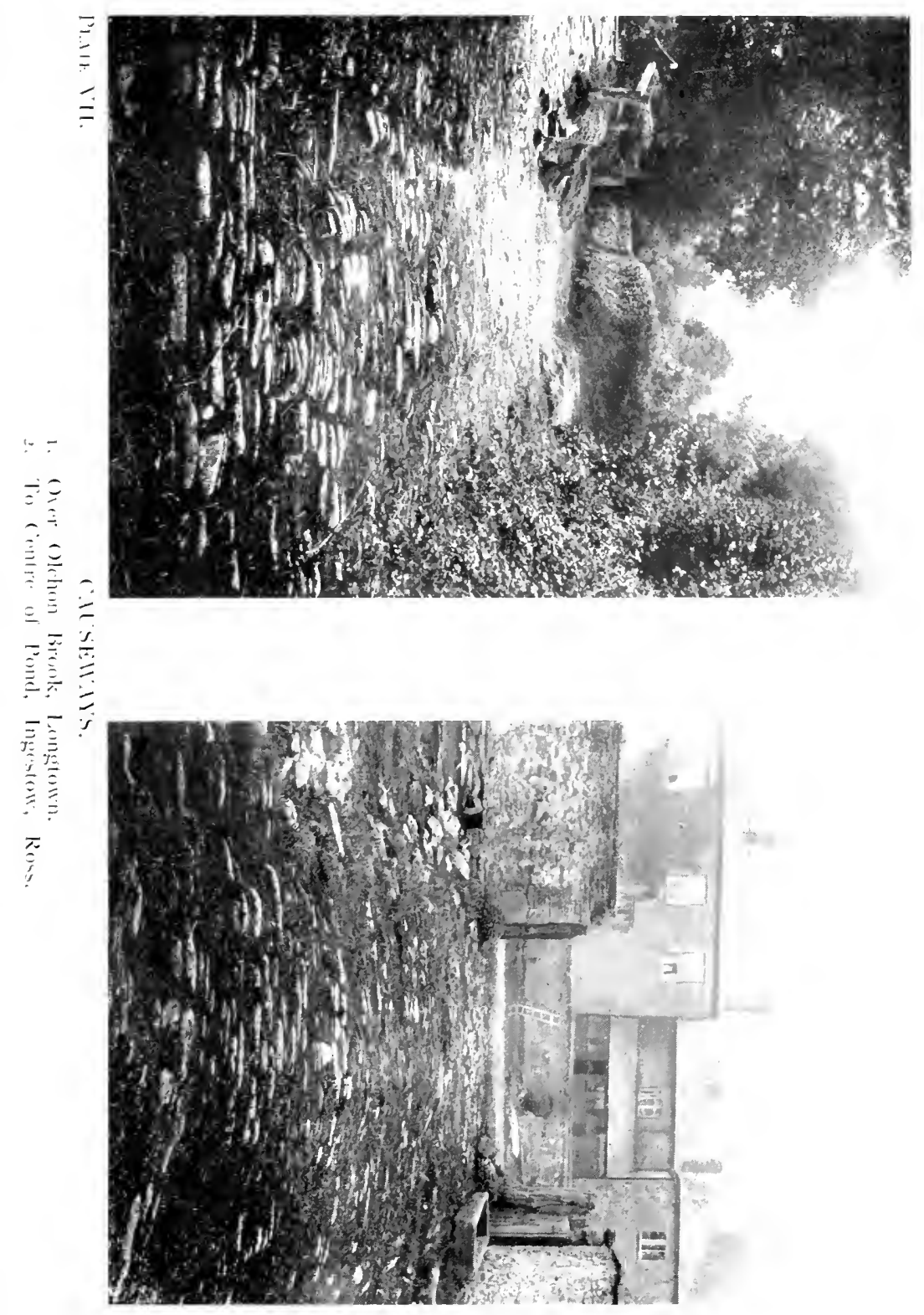



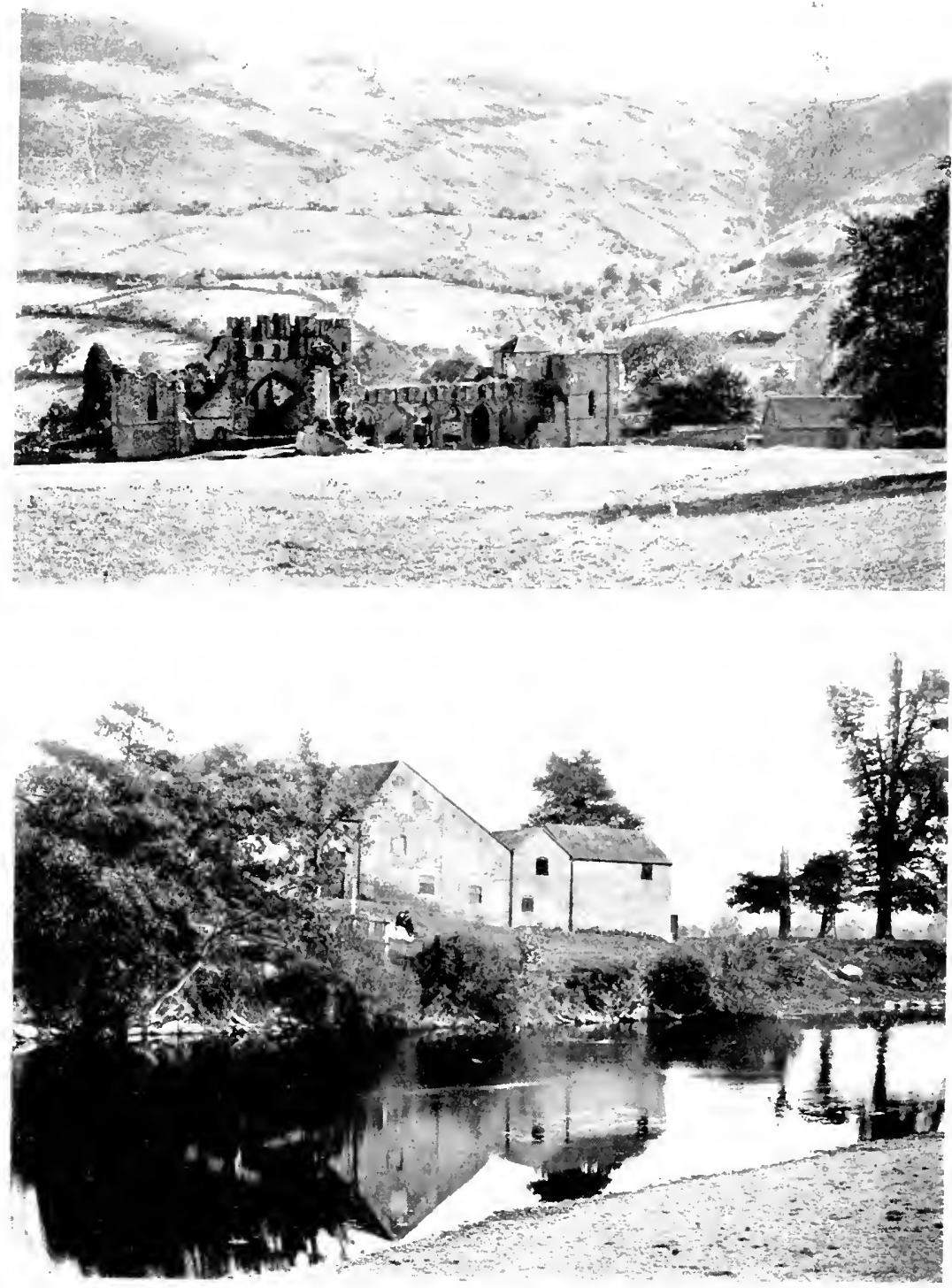

P1.17E I'III.

L.EYS IDISPL.IYED.

1. Track Climbing Ridge, Llanthong lbbey.

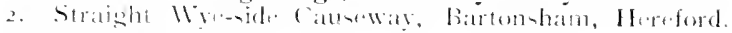




\section{TREES.}

I find that practically all the named historic trees (including Gospel Oaks) stand on leys. Such as King's Acre Elm, Eastwood Oak, Great Oak at Eardisley, Oak near Moreton-on-Lugg Bridge, etc. Place names (which in my previous articles on Crosses I too hastily held to signify the site of a cross) also indicate trees as marks. Such are Lyde Cross Tree, Cross of the Tree at Deerfold, Cross Oak, Cross Ash, Cross Colloe (hazel tree cross), and two leys cross at these points. Actual trees are shown at the cross roads in two of the above in Taylor's fine county map of 1757 .

The Oak in the horse-shoe meadow at Ross is on the ley passing over Over Ross (the place name indicates it) and Wilton Castle. The steep little street coming down to the river from the Swan Hotel is dead on this ley.

Where a natural hill came under a ley it was often made a sighting point by the planting of a single tree, hence the numerous " one tree" hills, as at Backbury and on the Holmer Golf Links. All places called "The Grove" seem to be on a ley, and a small group of trees (as at Ladylift) was also used to mark a sighting point. Existing trees are probably successors of original ones.

I see evidence that at one time such trees were called the "stock." The site of the wayside cross at Winforton is known as the Stocks, and a marking tump in the lane for Bowley Town (or Court) has an ash on it, and is called by the same name, as are farms at Wellington, Almeley Woonton, etc. The highest point (a hill near the Three Elms on the "Roman" road from Kenchester to Lugg Bridge) is marked on the map as Bobblestock Hill. I have known it as Bubblestock, but have no doubt it was Baublestock, the tree or stock (we still buy apple stocks in the market) where men who peddled necklaces and other baubles met the buyers. To-day, if you ask in a shop whether they keep such goods, you will, perhaps, be told that they have a good stock of them.

I think that the pole (Layster's Pole, Yarpole, Lyepole, etc.) was a form of sighting point, lingering on to recent times as the May pole.

Every considerable avenue of trees (as in parks of country seats) which I have tested has a ley down its centre.

Monnington Walks, a Scotch Fir avenue a mile long (Plate XIII.), is sighted through Monnington Church and the Scar Rock, Brobury, 
which last can be seen central in the picture. I found the ancient track still on the ley at the Scar, and alongside appeared to be an enclosed camp with defences of a mild type, such as seem to be alongside many other sighting points, as Longtown and Bridge Sollars Churches. Other avenues on leys are at Trewyn (two), where the house, central with the Scotch Fir avenue, has been proved to be on a burial mound, at Llanvihangel Court, where tradition also asserts the house (central again) to be on a burial mound ; at Oakley Park, Ludlow (The Duchess Walk); and at Longworth. A feature in most of these avenues is that, as far as present roads or tracks go, they "lead to nowhere," and the discovery of the ley solves this puzzle. A striking instance can be seen from the Castle Mound at New Radnor, from which Harpton Court and Old Radnor Church are in line, and the eye looks up the centre of an avenue of trees climbing to the church. That beautiful avenue (half its beauty gone since two recent gales) with the ancient name Green Crise, which lines a public road out of Hereford, is on a ley which comes down the County College Road, over Putson Ford, and passes through Aconbury Church.

One sure sign of a ley is a long straight strip of wood marked on the map, as from Franchise-stone to Litley, and towards Breinton Church.

The word "park" had a meaning different to its present usage, but was probably connected with woodland, and certainly with leys, which pass through each of the innumerable Park Woods and Park Farms.

The Scotch Fir or Pine is the tree which seems most characteristic of a ley, for a group of them are almost always (I notice) signs of a sighting point, as at Constable's Firs, Hampstead Heath.

At the present time it is impracticable to sight from point to point (especially on water points) on account of intervening trees. It is certain that for many centuries the sighting points were used, and that trees did not then intervene. This throws a doubt on the usual glib statement that ancient Britain was one dense forest. Perhaps the increase of trees was a cause of the decay of the system.

\section{CAMPS.}

I find that every camp seems to have several leys over it, and that these usually come over the earthworks, not the camp centre, as with moats. Also that camps almost always show signs of part of their earthworks being tumps. At Sutton Walls are four unmistakable tumps, in one of which an interment was found, and in another 
(Plate XIV.) the Club at its visit saw the bases of two masonry columns of Roman construction, the use of which seemed a mystery. I feel certain they were columns built by Roman surveyors for exact sighting.

Standing on the highest part of Dinedor Camp earthworks, the towers of Hereford Cathedral and All Saints' Church can be seen exactly in a line to the stand point.

The camp plans in past Transactions show signs of tumps in most camps. It is impossible to assume that leys (sighted between two mountains) should in the scores of instances exactly fall upon the earthworks of camps previously built on sites selected solely for defence. The leys came first, and the present camp was then merely the site of two or more tumps. There came a period of organised raids and war, and where a group of tumps gave the first elements of defensive works, they were joined by earthworks into a complete enclosure for defence. Here again sighting settled the sites of camps. Hereford Castle Green with Hogg's Mount the only remaining sighting tump, others (as at the Russian gun) being now levelled, is an example. Many groups of tumps, never developed into camps but sufficiently near to be so, are to be found on the map.

I found Caplar Camp to have so many leys over it as to seem the Clapham Junction of ancient trackways in that district. It may be that in a few cases of lofty camps (as Croft Ambury and Herefordshire Beacon) they form terminals of sighting lines, but in almost all cases the leys pass over them.

\section{CHURCHES.}

These-if ancient-seem to be invariably on (not merely alongside) a ley, and in many cases are at the crossing of two leys, thus appropriating the sighting point to a new use. A ley often passes through a tump adjacent to the church, and a cross ley through both church and tump. In other cases a mark stone site became the churchyard cross, and a cross ley comes through both church and cross. In many cases one of the leys went through the tower only, and it is possible that tower and steeple were built to be used as sighting points, although on the other hand a large church did in fact block the road. I will make no surmises on these interesting points. The sighting system may have been in decay or the tracks abandoned when the churches were first built on the sighting points. I do not think it probable that leys were made to provide sites for churches. 
In almost every old town or village will be found examples of a church built on and blocking an ancient road although new roads (as at Weobley) are often made on one or both sides. I show examples of a number. Broad Street blocked by All Saints, Offa Street (a striking example) with St. Peter's Tower dead on one end, and the Cathedral Tower dead on the other end. Other examples: Ledbury, Wigmore, Shrewsbury (Fish Street), Kington, and Madley, where tower, churchyard cross and village cross are on one ley, and tower, nave, chancel, and a mark stone in the village on a lengthwise ley.

At Warwick a chapel is over a town gateway, and in Exeter an ancient lane is also allowed to continue as a tunnel under the altar of a small church, two curious instances of the right of way being continued and the desire of the clergy to use the site also attained. Kenderchurch is a striking instance of a church perched on the apex of a sighting mound, and in other districts I can think of Bren Tor (Dartmoor), Harrow, Churchdown (Gloucester), and the two St. Michael's Mounts, these last obviously terminals of leys, as is St. Tecla's Chapel out in the channel below Chepstow, the termination of the beach ley which gives its name to Beachley Village.

In London St. Paul's blocks the Watling Street and Ludgate Hill leys, and St. Clement Danes, St. Mary le Strand, and St. Martin's in the Fields are all on another ley with subsidiary roads evolved on each side of the churches.

\section{CASTLES.}

Every castle in this district has a ley passing over it, and originated in a sighting tump, upon which the keep was afterwards built when some lord selected this as a desirable site for a defensive home. If a large tump, there were usually some excavations which were developed and extended into real defensive works.

The word castle is applied to many tumps (as in Moceas Park), where no building has ever existed, and to farms (as Castle Farm, Madley), where there are signs of a tump, but merely a homestead round it.

Where the word castle is part of a genuine place name, there was a sighting mound.

\section{TRADERS' ROADS.}

Salt was an early necessity, and "Doomsday Book" records Herefordshire Manors owning salt pans at "Wick," namely .Droitwich. The salt ley for Hereford came from Droitwich through the White House, Suckley, Whitwick Manor, Whitestone, Withington (site of present chapel), White House, Tupsley, Hogg's Mount, Hereford, 

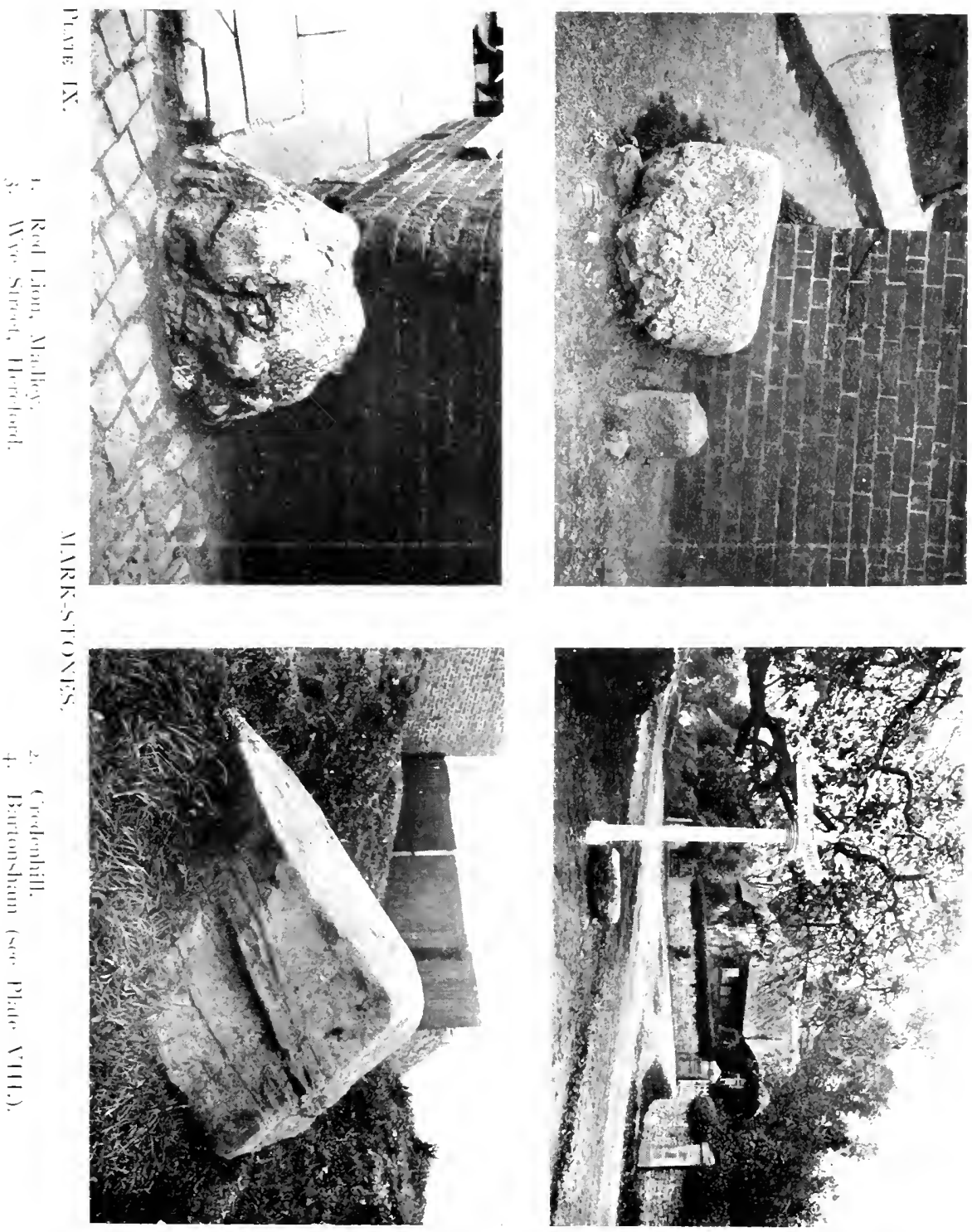

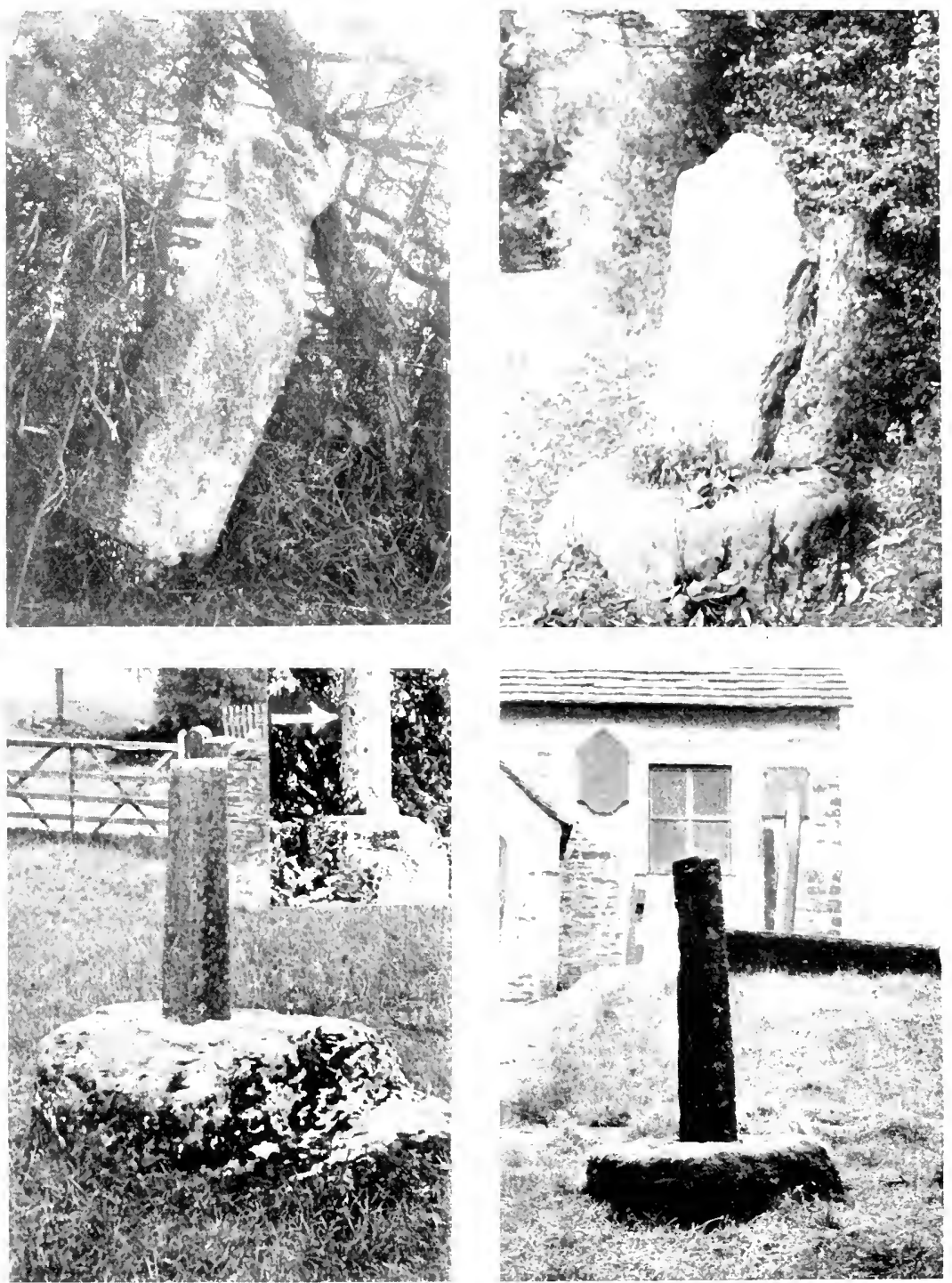

I'ATE X

长り

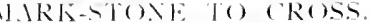

f. Predlar ('row, Llanison.

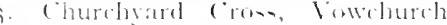

2 Niring stone.

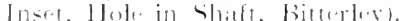

t. C'hurchyad Crom, Caye-r-Fin. 
and on to its terminal on Mynydd Ferddin Hill through Whitfield mansion. Another salt ley passes through Henwick and Rushwick (Worcester), over the Storridge pass through Whitman's Wood, and ultimately gets to White Castle (Mon.), passing over the White Rocks at Garway. Similar leys pass through such places as Saltmarshe Castle, Whitewell House, the two White Crosses, Whitcliffe, Whiteway Head, the Wych pass over the Malverns. It is plain what the "white" man carried.

A knowledge of the ancient pottery in the Kiln Ground Wood at Whitney enables me to show the meaning of the numerous red banks, barns, and houses. A ley through this pottery is sighted on Newchurch Hill and passes through Redborough, Red Lay (a cottage on main road this side of Letton); the ley is then dead on two miles of the present high road as far as the Portway, and passing through the Home Farm, Garnons (where the ancient road exists), it ultimately reaches the little Red House, the old Tannery House at The Friars, Hereford; the ley goes on through Woolhope Church, but the small local potter had come to his limit and the reds cease on this road. Another ley from this pottery runs through the Red Gates and Eardisley Park.

What the "black" man carried is indicated by the name still given to the smith who works in iron. Whoever carried to or from the local forges, whether it was ore, charcoal, or iron, would be black.

The earliest trade (before metals were worked) must have been in flints, and as a man who wanted such would not have gone across Gloucestershire to the nearest chalk districts to fetch them, the flint chippers, or knappers, would come on the road to sell them. The sighting tumps called the Knap are common, and if I wanted to search for flint flakes, I should go to the base of the Knaps, their earliest market. Tin Hill, Tinker's Hill, and Tinker's Cross have a similar meaning.

\section{HEREFORD TRACKWAYS.}

More than a score come through Hereford. There are sighting tumps at Hogg's Mount (Castle Green), Mouse Castle (also marked as Scots Hole), Gallows Tump (Belmont Road), Holmer Golf Links, Holmer Lane (top of old brick field), and an important one, Merryhill (in Haywood Forest), now marked as Beachwood. There also have been (now demolished) sighting tumps or points at Castle Hill, Palace Courtyard, Overbury (Aylestone Hill), The Knoll, Tupsley. And remains of one for the Castle ferry is on the line of earthwork bounding the Bishop's Meadow. 
A riverside track sighted over Hogg's Mount and Holmer Lane Tump is illustrated in Plate VIII.

I have found trackways through the sites of each of the ancient churches. St. John's Street extended passes exactly through the chancel of the chapel of the Knights of St. John of Jerusalem at Widemarsh. Barrol Street through the site of St. Guthlac's. In evening light a trackway can be seen from the Castle Green terrace, running through the large elm stump in the Bishop's Meadow to certain railings on the river bank, it runs by Vaga House, Quay Street, site of Blackfriars Church, northwards to Brimfield Church, and southwards through a moat this side of the rectory at Upper Bullingham. Other straight trackways are visible through an orchard behind Kilburn (Aylestone Hill), on this year's show-ground near the Three Elms, through Litley orchard, and descending the meadow on the north slope of Aylestone Hill to pass by the Burcott Pool, and on to Tenbury.

\section{TRADITIONAL WELLS.}

The ley brings to mind or discovers many of these, for a straight track went to or past all of them. There are Holy Wells at Dinedor, between Blakemere and Preston, and under Herrock Hill. As children, living close by, we used to call the Coldwell at Holmer the Holywell, and found our way by stepping stones to the ancient stone built well now destroyed. It was much like the Chamber well near the mill at Weobley. The Golden Well near Dorstone is on a ley running through Arthur's Stone, the Gold Post (a mountain cot), and terminating in Pen-y-Beacon. The two "golds" on one track indicate a trader's way. Leys go straight to, and not beyond, many wells in the Malvern ridge-St. Ann's, Holy Well, Walms (there is a Walmer Street named from a ley in Hereford and a surname Walmsley), St. Pewtress, and one (whose name I do not find) near the Chase Inn, above Colwall, which village itself is the Cole's-or magic man's-well.

I have photographed in Cornwall the pointed "beehive" stone structure covering a Holywell, surmounted by a cross; the whole obviously suited for a sighting point. Here and there, as at the Flintshire Holywell, a chapel has been built over the well. Our local example is at Marden, where the well, in the west end of the church, central with the nave (and the ley), is connected with the tradition of St. Ethelbert.

There is an ancient well in Goodrich Churchyard, with a track way obviously passing over it, but not through the church. 


\section{PREVIOUS DATA.}

A number of observers have recorded confirmatory facts.

Mr. G. H. Piper ("Woolhope Club Transactions, 1882," p. 176) says: "A line drawn from the Skerrid-fawr (mountain) northwards " to Arthur's Stone would pass over the camp and the southernmost " point of the Hatterill Hill, Old Castle, Longtown Castle, and Urishay "and Snodhill Castles."

Mr. Thos. Codrington ("Roman Roads in Britain," 1903) says : "Between the extreme points there are many straight pieces not "quite in the same line, generally pointing to some landmark. There " are several instances where a barrow or tumulus was the landmark, " the road passing round it on nearing it. Silbury affords one example, "and Brinklow, on the Foss, another."

Mr. James G. Wood ("Woolhope Club Transactions, 1910," p. 146) says: "The origin and purposes of these tumps associated "with Roman roads will well repay investigation. I have traced a " line of such works across South Monmouthshire and West Gloucester" shire from Caerleon through Caerwent into the Forest. All of these " are so placed that each is in sight of the next in either direction. "Again, we find that such roads were in many cases ranged or laid " out in line with small camps or such tumuli-being, in fact, surveying "stations."

The Rev. S. Baring-Gould ("Book of Dartmoor," 1900) says : "The stone row is almost invariably associated with cairns and "kistvaens. They do not always run parallel; they start from a "cairn and end with a blocking stone set across the line."

The Rer. S. Bentley ("History of Bosbury," 1891) says : "Under the cross in the churchyard, at its remoral to its present " site in 1796, a huge shapeless mass of rock weighing upwards of two "tons was found. This stone now lies in the churchyard close to " the tower on the south side." Another writer refers to it as "this "large unhewn mass of Silurian rock."

Mr. Hillaire Belloc ("The Old Road," 1904), writing of the Pilgrim's Way, says: "Now on its way from Winchester to Canter"bury the Old Road passes, not in the mere proximity of, but right " up against, thirteen ruined or existing churches."

Mr. Belloc also says: "The sacredness of wells is commingled " all through Christendom with that of altars"; and giving Continental instances, also refers to the one under the altar at Winchester. 


\section{ROMAN ROADS.}

The exact relation of Roman roads to the earlier leys is a matter for future investigation, but our co-member Mr. Jack is on the right lines when investigating the surface construction to find whether a road can be called Roman. It is not easy to realise that many British roads were as ancient to the Roman invaders as the Roman remains are to us.

My general impressions from observed facts are that the Roman surveyors used the sighting system; that they utilized the old trackways, imposing greater width and their far superior road surface and foundations; also that working during the degeneration of the ley system, they did not appreciate the long distance primary points, but working on short distance hills and points their roads are not so consistent and individual. I find evidence that they established their stations on the original leys, and that these were then so numerous as to form the boundaries of stations or towns, and thus decide their polygonal shape. It is also probable that a great many Roman roads of which portions remain were never completed, although the sighting points of the original ley continue on the line.

The road from Aymestry to Mortimer's Cross comes down to the Wye in the cutting at Bridge Sollars.

The "Roman" straight road from Leintwardine through Paytoe and Wigmore Hoor (the subject of recent digging) continues as a ley through Lucton and Kingsland Churches.

I consider the existing maps of Roman roads to have little value as being based on the assumption that there were no straight sighted roads before the Romans came, and that (quite illogically) such a road could go round corners, and had to follow the tracks over which some old writer had travelled. I find the so-called straight Roman roads, as from Kenchester to Lugg Bridge, to be really on several slightly diverging leys, three in this case.

\section{PLACE NAMES.}

The ley and its sighting points were earlier than homesteads, hamlets, or towns, and as the latter evolved on the tracks, place names naturally bear traces of their origin.

It is no reffection on philologists that, not knowing of the ley, they have made misinterpretations, and have a huge mass of corrections to make. In particular they will find a past neglect in translating place names in the light of traders coming along the road and meeting 


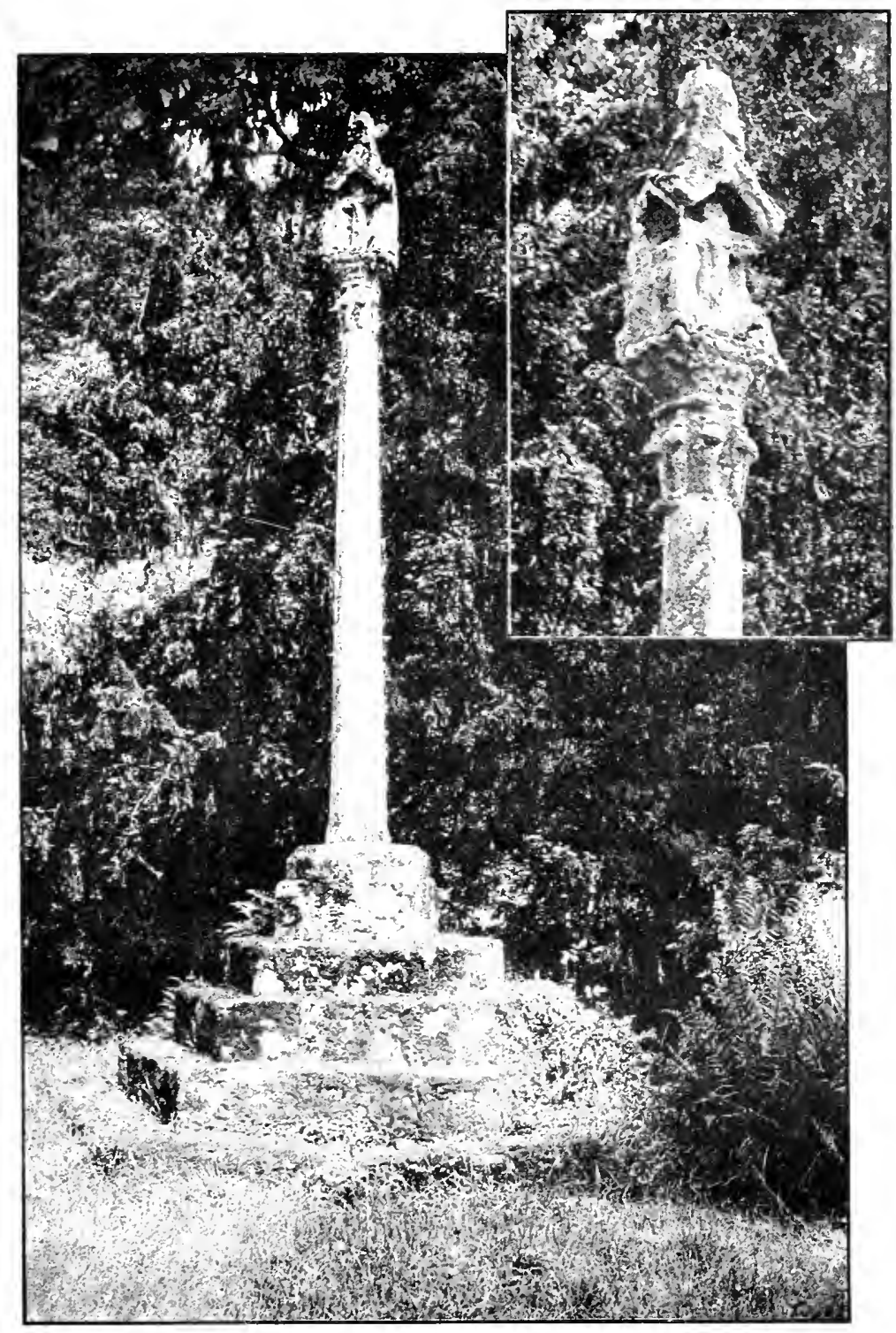

PL.17E XI.

(HER("HY.IRI) ('ROSS.

Bitterley. 


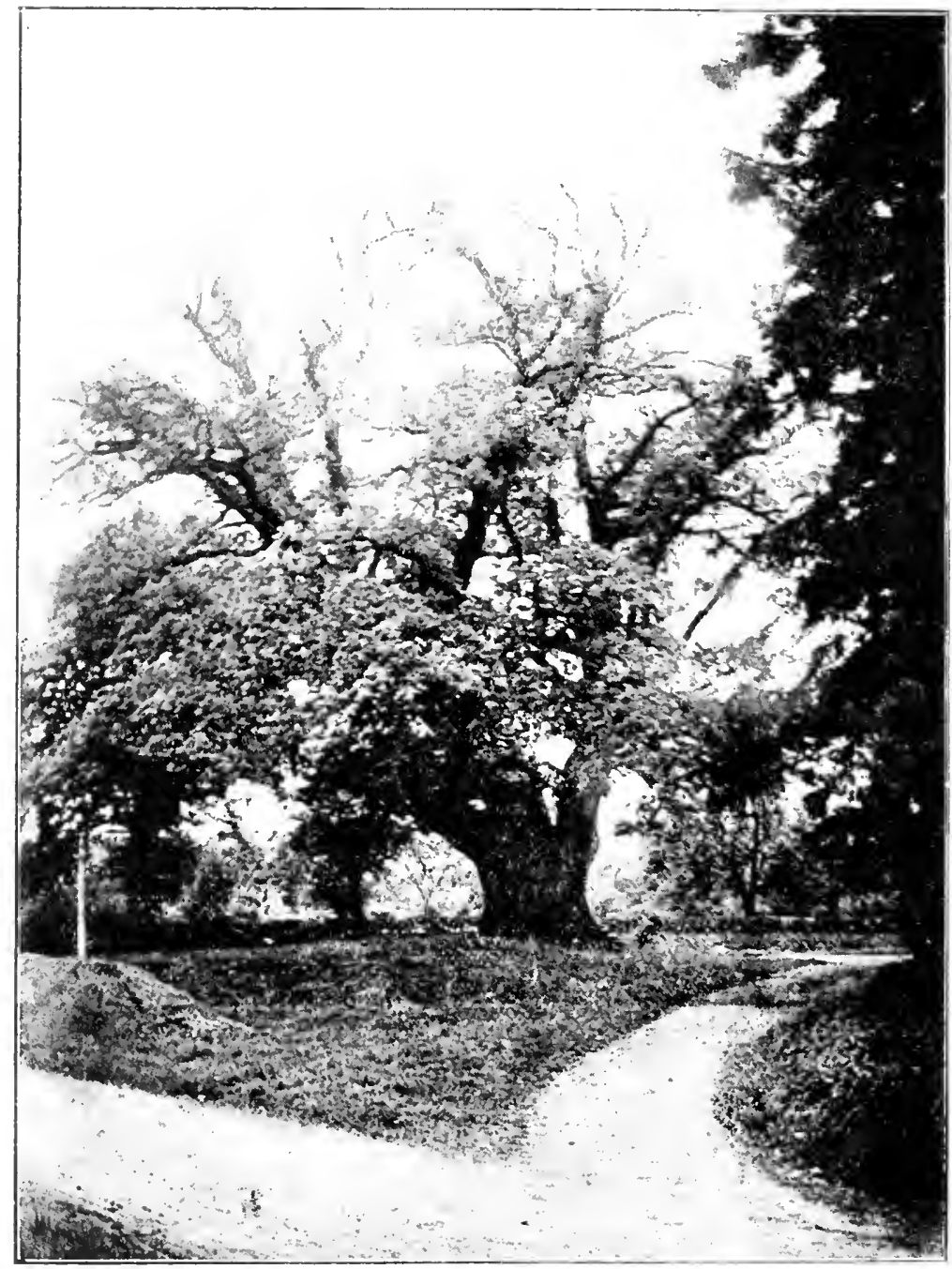

PIIE XII.

TREE

Eastwood Oak, Tarrington. 
the buyers at settled points. The man who brought the long-coveted gold ornaments might only come once a year, but to the women of the community the Gold Hill, Gold Post, or Golden Cross (roads), where they met him, or the Golden Valley, along which he came, would be likely to take their names from his wares. There are two of each of the above Gold place names in the county.

The notes which follow must be taken rather as suggestions than as final conclusions.

The common suffix-ley-indicates a ley of the character denoted by the first element in the name, and "meadow" is not, I think, the right interpretation. The numerous Leys Hills are not likely to be so called from meadows.

The suffix - ton originated by a mark stone on the ley becoming the nucleus of a homestead, and perhaps later a town.

The suffix-bury clearly indicates a mound which was a sighting tump. It is a strange development that these tumps were coveted both as places to be buried in and to live on. Mrs. Gillespie (who lived at Trewyn, Pandy, for 17 years) writes me: "I suppose you know that Trewyn was built on a burial mound," and goes on to describe the discovery of a cist with human remains which they dug up under one of the rooms. I had told her how Trewyn was on two leys (therefore on a sighting point), one being down the avenue of ancient pine trees straight for Alt-y-Ynis.

Barrow (another mound name) occurs at Cradley, Pembridge, and Wheelbarrow Castle, Leominster; Canon Bannister shows that Coldborough was formerly Colbarwe, and he also associates borough and bury as from the same root. A variation is berrow as in Broomsberrow. Just as the sighting stone-ton became the site of our modern town, so the mound evolved into the borough.

Low-the universal name for the mound in Derbyshire-is not so common here. But Wormlow Tump, Ludlow, Warslow, and Bradlow indicate sighting points.

Bury is used alone as the name for a tump, as in the many Bury Farms, or as at Ivington Bury. A farmer still calls the earth covered tump in which he winters his roots a bury. Towns like Ledbury first grew round a sighting mound.

"Broom" occurs with great persistence on leys, with its variations brom and bram. Bromley and Bramley, Bromton and Bramton, Bromfield (where is the Old Field with a number of tumuli), Broomsgreen, Broomsberrow, and the many Broomy Hills are examples. It is not confined to one form of sighting point, and I surmise (from 
a faint line of evidence) that a eomponent part of our modern broom was an essential working implement of the skilled ley man, and was continued as the staff of the mediæval pilgrim. Whether the plant broom was the original root word or a derivative I cannot say.

Lady Lift (a hill-point mound) is on a ley with Lady Harbour Farm, and the prefix Lady is applied to court, grove, ridge, oak, and meadow in the county. The Lady Harbour of Hereford Cathedral is on one of the leys which form Church Street, and had the name before any chureh was built there. It might possibly indicate a woman's shelter on the road.

The suffix-tree, probably originated in a single tree planted as a sighting point, either as at "Cross of the Trce " in Deerfold Forest, or to mark the apex of a natural hill as illustrated in Plate XII. Webtree is on such a hill with two leys passing through it. Its name signifies that it is the spot where the webbe or weaver met his buyers. He travelled along the webbe-ley, and there are three Weobleys (formerly Webbeley) in the county, at Weobley Ash, and Weobley Cross, also the better known townlet. He also met others at a mark stone now known as Webton. The surnames Webb, Webber, and Webster still survive.

In the same way another first word element gave the place names (and surnames from them) of Bosley (Cattle-ley), Boston, Bosbury, Boswell, Bostock, and Boseastle. Again, Stanley, Stanwell, Stanton, Stanbury, and Stanbatch. And I have shown how the white (salt) man gave the first element to innumerable place names on his route. There is a Silver Tump and a Brass Knoll in the Olchon Valley, both proved sighting tumps.

The names Bowley, Bowling Green (farm, also a quarry near Ewias Harold), Bolitree, Bolstone, Bollingham, Bal Mawr, Balls Cross, Ballgate, Bellgate, Bellimore, and Belmont, all seem akin to the rounded outline of an inverted bowl, or to boils, bowels, and belly of animal life, and indieate the rounded tump.

The house at Bolitree is built on a tump with signs of a moat, and as I found a ley through Bollingham (house and chapel) I went there to find the bol, and there it was, a fine tump with an old summerhouse on its summit.

Gate in a place name (as in Hill Gate, Three Gates, Ballgate, England's Gate, Burley Gate, etc.) did not mean, as now, something which stopped a way (that was called a lid-yatt), but the way itself. It is mueh the same as the word pass. The same element (modified) is in such names as Gatley, Gatsford, Yatton, Symonds Yat, Woodyatt's Cross. 
Lee Line and Timberline Wood are place names clearly describing leys. There is a Linton and a Linley at Stanford Bishop-the mark stone and the ley. I think that Lyonshall, Lynhales, Lion Farm, and Hobby Lyons are variations.

Such names as Winslow, Preston Wynne, Winsley, and Winyard (Radnor Forest) indicate the road by which wine was brought. Totnor, Totteridge, Tothill, and Twt indicate (as Mrr. J. G. Wood has pointed out) tumps, and they are all sighting tumps on leys. Mr. Wood (who has come very near discovering the ley) also-in Woolhope Transactions for 1919-connects Titterstone, Clee Hill (Plate I.) with the word Tot or Toot. Tooting and Tottenham are London forms of the word. Rosemary Topping (English Bicknor) is a much prettier name for a sighting tump.

Bur or Burl seems to be descriptive of some form of sighting: point. Leys pass through Burley, Burlton, Burton (many of this name), Burford, and The Burcot; and there is a Burl Hill in Radnorshire.

Although a ley ran from peak to peak there must have been an earlier termination to its useful part, or a still more restricted part used by traders. Hence--in London-Finsbury; Capel-y-fin in the Black Mountains; and Fine Street, near Letton, have probably the same meaning, which, however, seems to be locally more often expressed by the word end, as in New End (Canon Pyon), Red Wych End (Cowarne), Nupend, etc.

As regards the place name element "broad" (also brad and bred), a ley passes through Broad Green (Orleton), The Broad, north of Leominster, Broadward, south of Leominster (dead on the main road at each of these two), and on to Broadlands at Aylestone Hill, Hereford. It was the road, not the place, which was broad, constructed for wheel traffic, for which the previous pack-horse tracks were too narrow. Mr. Allan Bright, of Barton Court, Colwall, wrote me, pointing out that a ley from the Wych through his house to Ledbury Church, also ran through a meadow of his called Broadley Meadow. Such names as Bradley, Bradlow, Bradford, Broadmoor, Broad Oak, and Bredwardine are thus explained.

Probably most instances of the word elements, little and long, apply to the roads which pass through the places. Hereford is (no doubt correctly) said to mean "army road." Little Hereford is not a small edition of the town, but of the road. Litley is the small ley, Longley is the long ley, and so with the stone, grove, land, and ford 
(there have been two Longfords). Long in old spelling was often lange ; and little, lutel or luttel-these from Canon Bannister's list. Hence come the (places and surnames) Langstone, Langford, Langland, Langton, Lutley, Luton. The two Leinthalls-Earles and Starkes-are seldom called by these second names locally, but are Little Leinthall and Long Leinthall respectively, the element leint (occurring also in Leintwardine) being I surmise derived from ley. Little Leynthale, to quote an old spelling, would be the meadow traversed by the short ley.

\section{DISCOVERY BY PLACE NAME.}

I have experienced this in several cases, and will detail one. A local antiquarian (Mr. W. Pilley) always maintained that there had been an ancient spring-the Bewell spring-close to Bewell House and the Hereford Brewery within the City. When I lived there with my father we knew nothing of it. But about a year ago the present owners in sinking a new deep well and building a new engine house, uncovered the following inscription cut in stone in the base of the brewery wall, but covered by a rockery in my time :-

\section{WELL, 71 FEET, 1724.}

I had always felt that the derivation given for the place name Bewell Strect as Behind-the-wall Street was an error.

There is a hill on the Canon Pyon road called Bewley or Bewdley Pitch. Solely on account of my surmise that the Bew-ley might lead to the Bew-well, I tried a line on the map and found a ley exactly falling on this "pitch" (or steep road) passing from the north through Bishops Moat (west of Bishops Castle), Neer Oak, Bucknell Church, Street Court, Stretford Churchyard, and Birley Churchyard, and exactly over the site of the well. Southwards over Palace Ford, Dinedor Camp, Caradock, Picts Cross, Hom Green Cross, Walford Church, Leys Hill, Speech House ; there being numerous confirmations in fragments of road.

\section{THE LEY-MEN.}

The fact of the ley, with its highly skilled technical methods, being established, it must also be a fact that such work required skilled men, carefully trained. Men of knowledge they would be, and therefore men of power over the common people. And now comes surmise. Did they make their craft a mystery to others as ages rolled by. Were they a learned and priestly class, not admitted until completing 

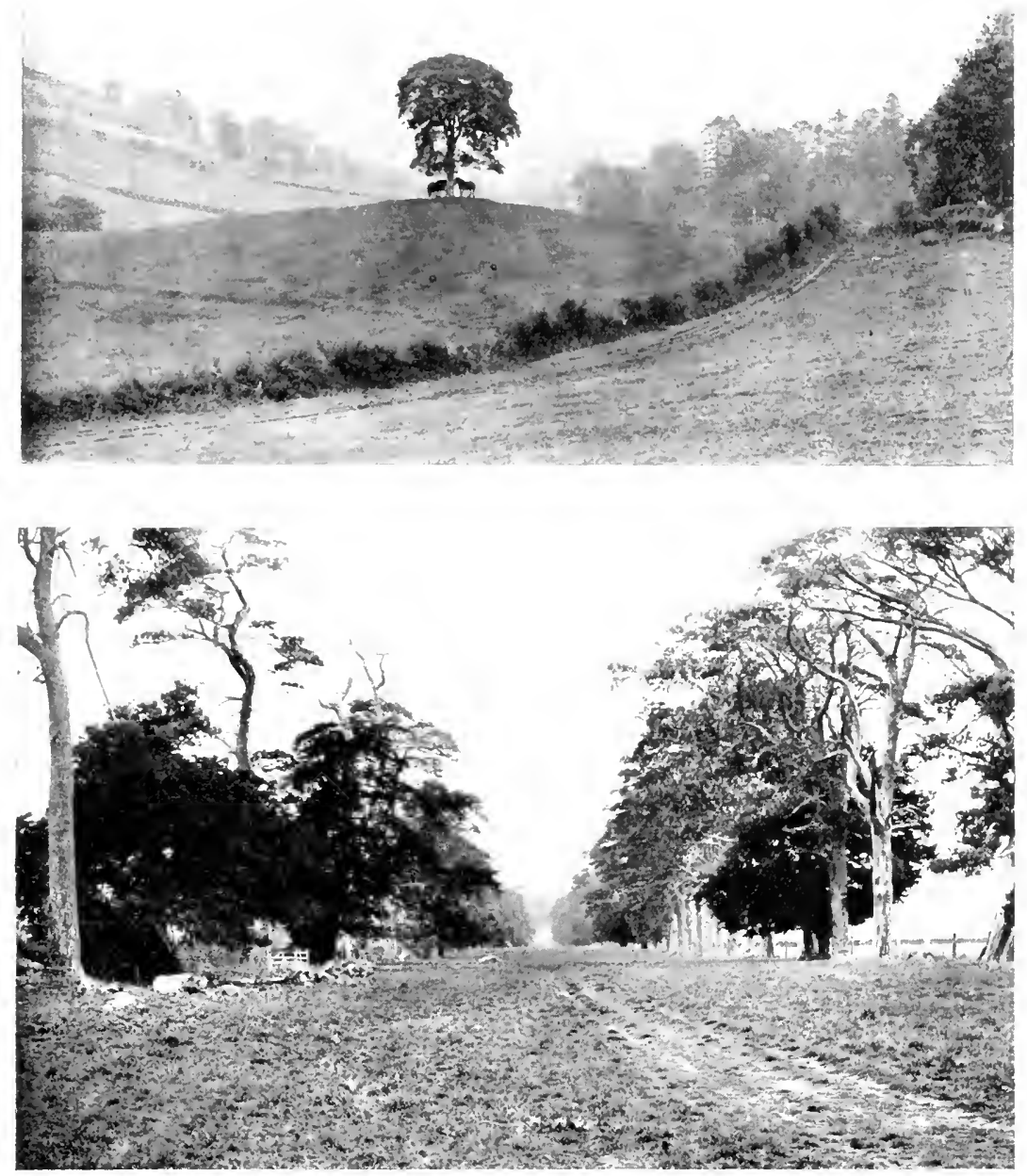

I'LATE XIII.

TRELS.

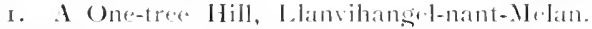

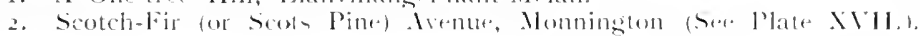



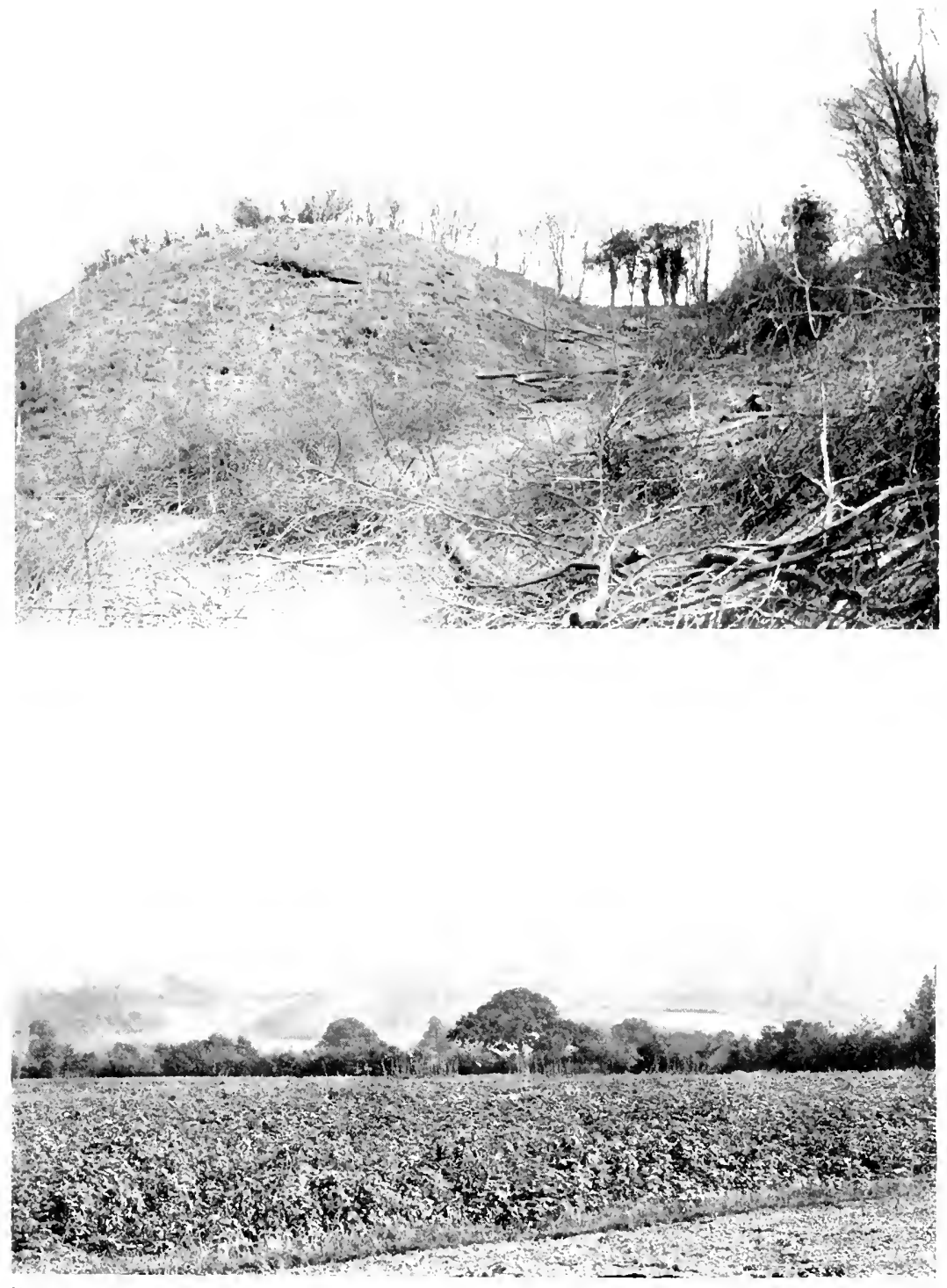
1'1. II: XII.

C.I.IIIS.

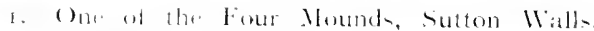

2. Herefordahire beacon. 
a long training -as Cæsar describes the Druids. Or did they-as Diodorus and Strabo says of Druids-become also bards and soothsayers. Did they, as the ley decayed, degenerate into the witches of the middle ages. Folk-lore provides the witches with the power of riding through the air on a broomstick, the power of overlooking, that of the evil eye. They (in imagination) flew over the Broomy Hills and the Brom-leys. It may be that the ancient sighting methods were condemned as sorcery by the early Christian missionaries.

Were they the laity or lay-men of Beowulf ?

In later days our first English poet was one Layamon, and in his time were men called Ley-cester, Leye, and Ley-land.

In the Oxford Dictionary is given the obsolete word cole as meaning in the 16th century a false magician, a juggler, and coleprophet (or cold-prophet) with a similar meaning, and there is a colestaff or cowl-staff also mentioned, which, although then meaning a carrying stick, was-I surmise-originally the working sighting staff of the cole-man, who was the magician of the ley. The word still survives in colporter, a walking seller of books, who carries his wares slung over his shoulder on a stick.

We have in our district Coldman's Hill, Coldstone Common, Coles Tump (Orcop), and Coles Mountain (Presteign). In other parts of England are Coley, Colbury, Colebatch, Colestock, Coleshill, Coleford, Coleham, Colchester, and Coleridge, which last has an alternate name Coldridge, confirming other instances of the intrusion of the d. I surmise Cold Harbour (Kentchurch) to have been Cole Harbour.

Colmanswell in Ireland possesses to-day a "sacred" well, and this name, together with our own ancient Colewelle in Herefordshire, now altered to Colwall, is probably nearer the original root meaning than is the case of the three Coldwells at Holmer, Kingston, and English Bicknor.

A Bishop's name Colman is mentioned in the Anglo-Saxon Chronicle, and Cole is also a common surname to-day.

There are other names for a ley-man indicated in the two Derbyshire place names, Totmans Low and Laidmans Low, the Low being a sighting mound.

\section{HINTS TO LEY HUNTERS.}

Keep to the discovery of lines through undoubted sighting points, as artificial mounds (including castle keeps), moats and islands 
in ponds or lakes. In practice churches can be treated as sighting points, but in some cases a ley passes through a tump or well close to the church. Avoid for a time the temptation of taking every bit of narrow straight road and extending it into a ley. Scrap every ley you think you have discovered if it does not pass through at least four undoubted sighting points exclusive of roads.

You must use Government ordnance maps. One mile to the inch is the working scale. Other maps of two or four miles to the inch are quite useless, save for checking long leys.

The (B) "Popular edition, mounted and folded in covers for the pocket," is the most convenient for field work and is the cheapest, as it contains over double the area of the older (C) $18 \times 12$ edition ; but I have found the latter (uncoloured, in flat sheets) necessary for transferring leys from one map to the next on drawing boards in the office.

Maps cut in sections are useless for this exact work.

About four drawing boards, a light 24-inch straight edge, a $\mathrm{T}$ square for pinning down the maps accurately to line with the boards, a moveable head $T$ square to adjust to the angle of the ley, so as to transfer to the next map, and a box of the glass headed pins used by photographers (in addition to the usual drawing pins) are the minimum essentials for real work. A sighting compass for ficld work used in conjunction with a special divided quadrant on the moveable head of square are aids I have found valuable.

Remember that the entire course of a ley can be found from two undoubted sighting points on it if marked on the map. Therefore stick a glass headed pin in these two points, apply the straight edge, and rule the line, pencil it at first, ink afterwards.

When you get a "good ley" on the map, go over it in the field, and fragments and traces of the trackways will be found, always in straight lines, once seen recognised with greater ease in future.

Where close detail is required, as in villages and towns, the $l^{\prime \prime}$ scale is far too small, and the $6^{\prime \prime}$ scale is necessary. The angle of the ley is transferred to it from the $1^{\prime \prime}$ map with the aid of the moveable head square. Maps must be pinned square on the board by the $T$ square passing through identical degree marks on the edges, latitude for leys running $E$. and $W$., but longitude for leys $N$. and $S$. The edges of the maps are not truly in line with the degree lines, and must not be the guide.

Ley hunting gives a new zest to field rambles, and the knowledge of the straight ley provides new eyes to an eager observer. 
I have a mental vision of a Scout Master of the future, out ley hunting with the elder boys of his troup, instructing them as they look out from a high sighting point. "Now, Harold! if you only " take that pole out of your eye, you will see better to pick out that "distant moat that Cyril has in his eye. He's got it, right enough, " just a speck of light from the ring of water round the island. When

"I told you to use your pole as a sighting staff, I didn't tell you to "see nothing else. Now we have found the ley, I think we shall see " a bit of the old track in that far grassy field this side the moat ; it's " narrow and straight, and there are many who never find it because "they look for a broad way like our present wheel tracks."

\section{A FEW LEYS.}

\section{(Additional to others detailed in text and maps).}

Colva Hill to Birdlip Hill, via Parton Cross, Breinton Camp and Ford, Red Hill, Holme Lacy House, Caplar Camp, Yatton Church, Moat and Camp beyond Newent, and dead on "Ermin Street" for five miles.

Gwaun Ceste Hill to Brimpsfield Castle, via Michaelchurch, Eaton Camp, Perry Hill, Dinedor Cross, Tump, Brockhampton Old Church, Cross in Hand, Upton Court, The Conigree, Rudford Church, Gloucester Cathedral, Castle Hill, Witcombe Park, and Blacklains.

Gwaun Ceste Hill to West Tump, via Colva Church, Brilley Green, The Scar Rock (Brobury), down Monnington Walks (central), Monnington Church, The Chantry, Perrystone, Mullhampton, Anthony's Cross, Tibberton Court, Llanthony (Glos.) Abbey, and dead on a Gloucester street.

Little Mountain (Westbrook) to St. Ann's Well and Priory Church, Malvern, via Arthur's Stone, Cross End, Moccas Church, Monnington Church, Credenhill (old) Court, Pipe and Lyde Church, and Beacon Hill.

Pen-y-Beacon to North Hill, Malvern, via Sugwas Park, Ten Houses Pond (Plate VI.), Burcot Pool, White Stone Chapel, Shucknell Hill, Stretton Grandison Church, Moat at Birchend, and Mathon Church.

Croft Ambury to Y-Fan-Drongarth (2,410 peak in Brecon Beacon group), via Hill Barn, Easthampton, Milton House, Court of Noke, Elsdon, Bollingham Chapel Tump, Clyro Church, Llowes Church, Bryn-Rhydd, and Slwch Camp, Brecon. 
Bailey Hill (Knighton) to May Hill (Longhope), via The Warden, Presteign, Golf Course Tump, Holmer, Holmer House, Holmer Lane Tump, Venn's Lane, The Prospect and Tupsley Hospital Road, Main Street and Church, Fownhope, Caplar Camp, How Caple Church, Old Gore Cross, and Linton Church.

\section{ENDWORD.}

I close up my patchwork pages for this booklet, and a tired brain finds relief in two memories. The one of the day, just on half a century ago, when, a lad on a trader's route for my father's brewery, I pulled up my horse to look with wonder at the Four Stones, standing like sentinels in a field corner. Later in the same day, the steep slope of the Radnor Forest surmounted, came the first view of Castle Tomen at the summit of the Forest road, with its background of Wye and Irfon Valley (Breconshire) Mountains. And the note of unsatisfied wonder struck that day has lingered through nearly fifty years' unusually intimate knowledge of our beautiful West Country border land, and I know now that my sub-conscious self had prepared the ground and worked at the problem I now see solved.

The second memory is the vivid one of the rush of revelations in the gorgeous year of sunshine just finished. And I can scarcely realize that half the year had gone, the clear smoke-free distances of early summer a thing of the past, and midsummer day over, before I got the first clue. Once started, I found no halt in the sequence of new facts revealed by active search on the tracks.

It is a mere framework for a new knowledge that I offer, but I know that it has solid foundations, and that good wholesome field work by others-for it may not be granted to me to do very much more-will fill in many gaps. That is why I write.

PostSCRIPT. In some districts-as Salisbury Plain and the Yorkshire Wolds-there are groups of adjacent barrows so numerous that it is probable that most of them were built as burial mounds only, not sighting mounds. This is not the case in the district investigated. 


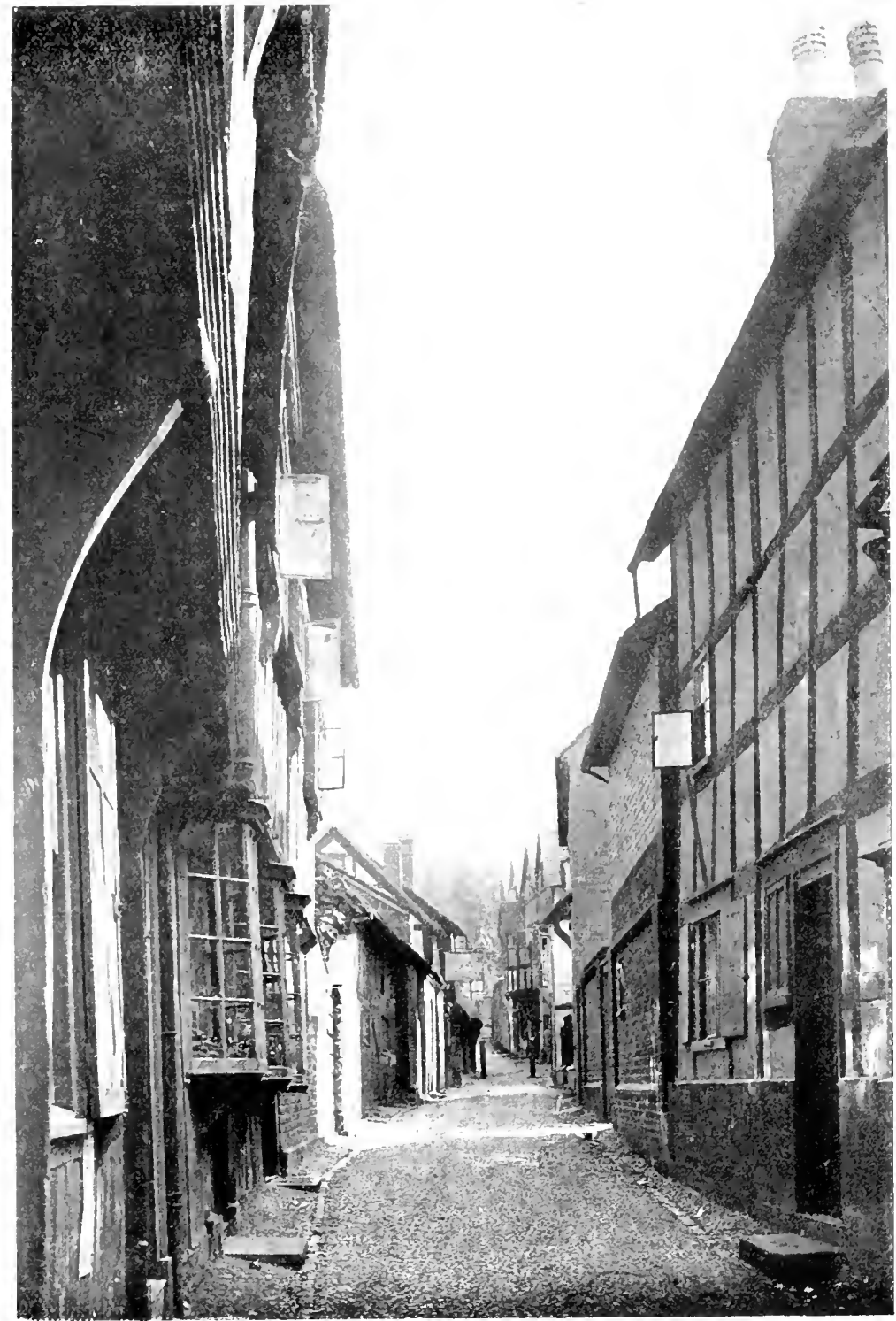

Pi.ate XV.

CHURCH.

Ledbury, the Spire sighted up Church Lane. 


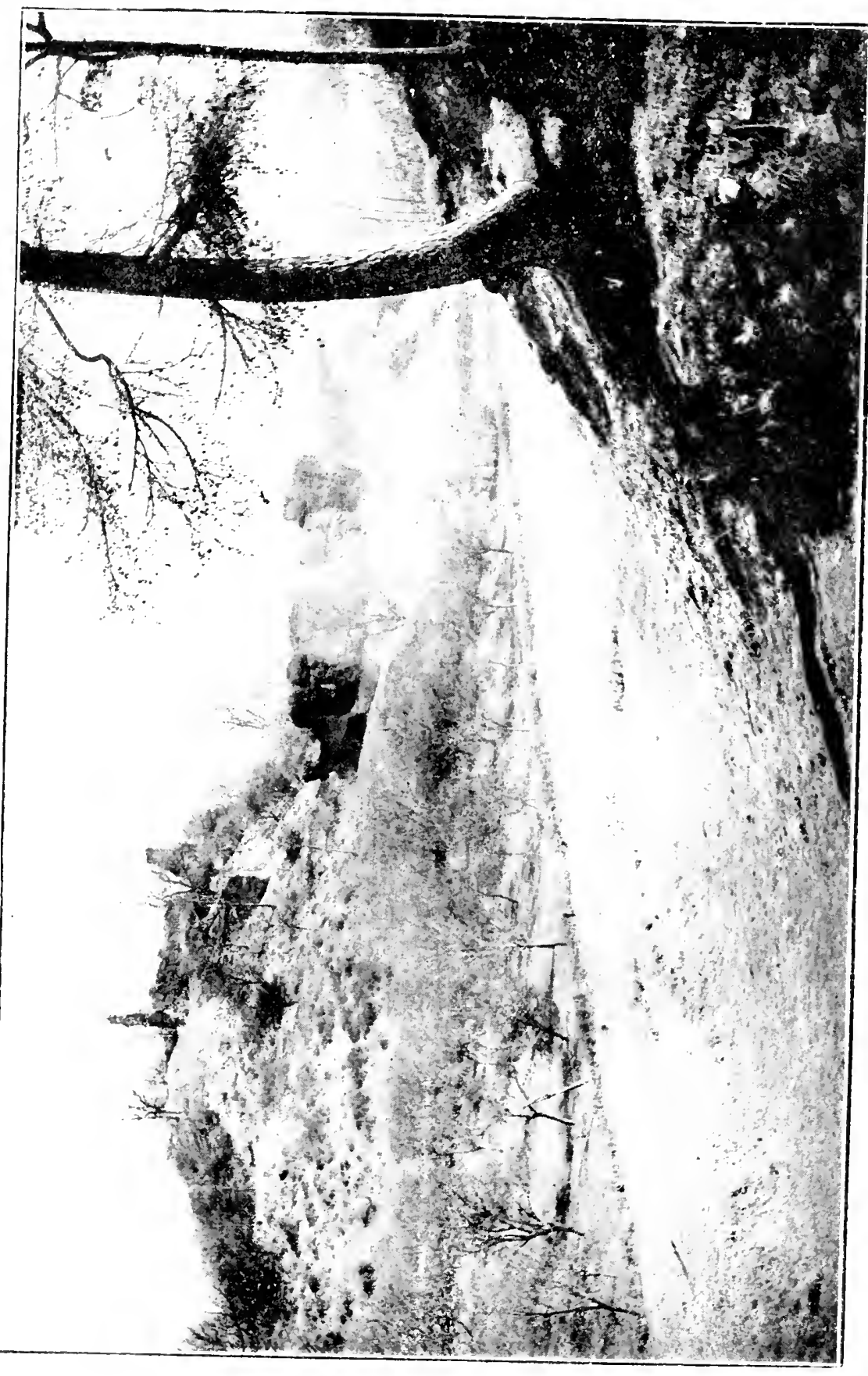

年 


\section{INDEX.}

Most of the Places indexed are in Herefordshire; those in adjoining counties are, if necessary, indicated by the initial of the county (as $R$. for Radnor) following the name.

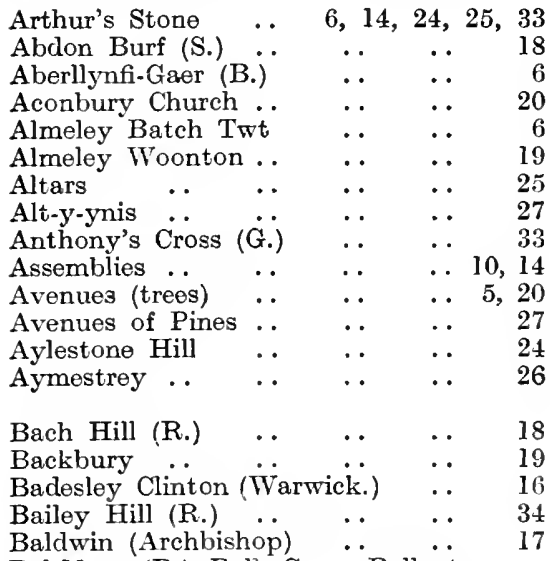

Bal-Mawr (B.), Balls Cross, Ballgate,

Bannister, Rev. A. J. .. . . 27, 30

Baring-Gould, Rev. S. .. .. 25

Barrow $\ldots 10,27$

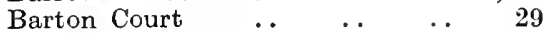

Bartonsham Farm $\quad \ldots \quad \ldots \quad 5,17$

$\begin{array}{llllll}\text { Bassam } & \ldots & \ldots & \ldots & \ldots & 5,17\end{array}$

$\begin{array}{llllll}\text { Batch } & \ldots & \ldots & \ldots & \ldots & 6,10\end{array}$

Beachley (G.) _. $\quad$. . $\quad \ldots .22$

Beachwood Hound $\quad \ldots . \quad \ldots \quad 23$

$\begin{array}{lllll}\text { Beacon Hill } & \ldots & \ldots & \ldots & 33\end{array}$

Bellgate, Bellimore, Belmont .. 28

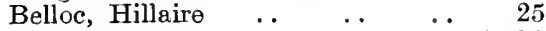

Belmont $\quad \ldots \quad \ldots \quad \ldots \quad \ldots \quad 16,18$

Bentley, Rev. S. .. .. . . 25

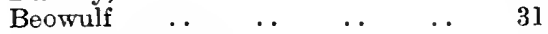

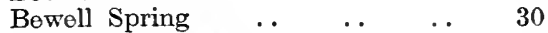

Bewley or Bewdley $\quad \ldots \quad$.. 30

Bible parallels $\quad \ldots \quad$. . $\quad \ldots .33$

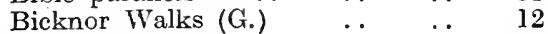

Birdlip Hill (G.) $\quad$. $\quad$. $\quad$.. 33

Birchend Moat $\ldots \quad$. $\quad \ldots \quad 33$

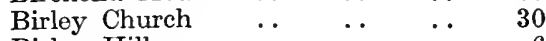

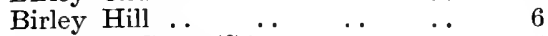

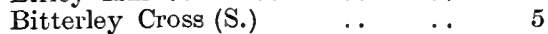

Bitterley (S.) _. $\quad \ldots \quad$. . 4,18

Bishop's Moat (S.).. $\quad \ldots \quad \ldots \quad 30$

Black Darren _.. $\quad$. $\quad \ldots .44$
Blackfriars, Hereford _. $\quad$.. 24

$\begin{array}{lllll}\text { Blacklains (G.) } & \ldots & \ldots & \ldots & 33\end{array}$

Black Mountains .. $\quad \ldots \quad \ldots \quad 5,17$

Black Traders road $\quad \ldots \quad \ldots .23$

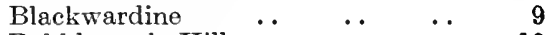

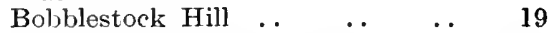

Bolitree, Bolstone, Bollingham .. 28

Bollingham $\quad \ldots \quad \ldots \quad$ 17, 33

Bosbury, Boston, Bosley .. 28

Bosbury Cross .. $\quad \ldots \quad \ldots .25$

Boswell (Staff.), Bostock (Staff.),

Boscastle (Cornwall) .. .. 28

$\begin{array}{llllll}\text { Borough } & \ldots & \ldots & \ldots & \ldots & 27\end{array}$

Bowley Bowling Groen $\quad \ldots \quad 19,28$

$\begin{array}{lllll}\text { Bowley Town } & \text {. } & \text {. } & \text {.. } & 14\end{array}$

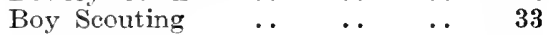

Bradley, Bradlow .. $\quad$.. $\quad 27,29$

$\begin{array}{llllll}\text { Bramley } & \ldots & \ldots & \ldots & \ldots & 27\end{array}$

$\begin{array}{llll}\text { Brampton Bryan } & \ldots & \ldots & 6\end{array}$

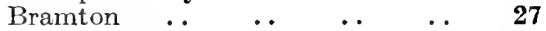

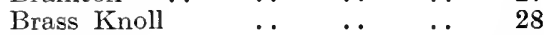

$\begin{array}{lllll}\text { Bredwardine } & \ldots & \ldots & \ldots & 29\end{array}$

Breinton $\quad \ldots \quad \ldots \quad \ldots 20,33$

Bren Tor (Devon) $\quad$. $\quad \ldots 22$

Bridge Sollars $\quad \ldots \quad \ldots \quad 16,20,26$

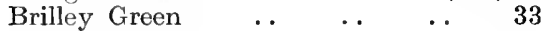

$\begin{array}{llllll}\text { Brinsop } & \ldots & \ldots & \ldots & \ldots & 16\end{array}$

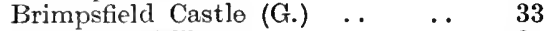

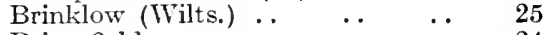

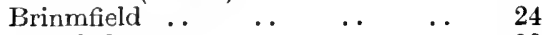

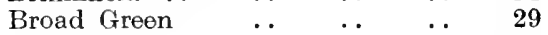

Broad (The) $\quad . \quad$.. $\quad \ldots \quad 9,29$

Broadlands, Broadley, Broadward 29

Brobury Scar $\quad \ldots \quad \ldots \quad 5,6,19,33$

Brockhampton Church .. $\quad$.. 33

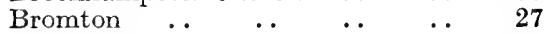

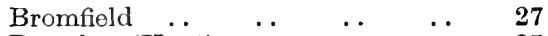

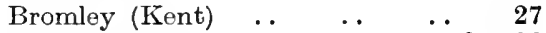

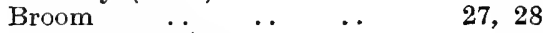

Broomsgreen (G) $\quad \ldots \quad \ldots \quad \ldots \quad \ldots \quad 27$

Broomsberrow (G).. $\quad$.. $\quad \ldots .27$

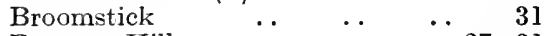

Broomy Hill $\quad \ldots \quad \ldots \quad$ 27, 31

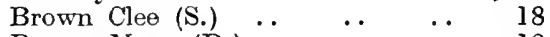

$\begin{array}{llll}\text { Bryn-y-Maen (R.) } & \text {. } & \ldots & 18\end{array}$

$\begin{array}{llll}\text { Bryn-Rhydd (R.) . . } & \text {. } & \text {.. } & 33\end{array}$

Bucknell Church (S.) $\quad$. $\quad$.. $\quad 30$

$\begin{array}{lllll}\text { Bullingham .. } & \ldots & \ldots & \ldots & 24\end{array}$

Burcot Pool $\quad \ldots \quad \ldots \quad 16,24,33$

$\begin{array}{llllll}\text { Bury } & \ldots & \ldots & \ldots & \ldots & 10\end{array}$ 
Burial Mound

$14,20,27$

Bur, Burton, Burford, Burcot .. 29

Burl, Burley, Burlton .. .. 29

Burley Gate $\quad$.. $\quad$.. $\quad \ldots .28$

$\begin{array}{llllll}\text { Bury } & \text {. } & \ldots & \ldots & \ldots & 27\end{array}$

Bush Bank .. $\quad \ldots \quad$.. $\quad \ldots \quad 17$

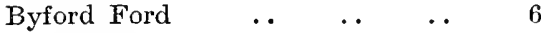

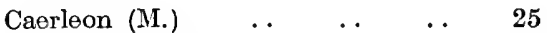

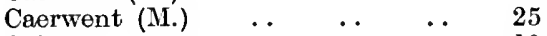

Cairn $\quad . . \quad \ldots, \quad \ldots, \quad \ldots, 10$

Camps-6, 9, 10, 11, 12, 15, 20, 21, 22, $25,33,34$

Canterbury

13,25

Capel-y-fin (B.) $\quad . \quad 5,17,18,29$

Capel-y-tair-ywen (B.) $\quad$. $\quad$. 6

Caplar Camp $\quad \ldots \quad \ldots \quad 21,33,34$

Caradock $\quad . . \quad \ldots, \quad \ldots, \quad \ldots, 30$

Castles-4, 6, 10, ii $, 20, \ddot{2} 1,22,23,25$,

28, 31, 33

Castle Hill (Glos.) .. . . . . 33

Castle Hill (Hereford) . . $\quad 14,23$

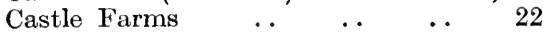

$\begin{array}{lllll}\text { Castle Tumps } & \text {. } & \text {.. } & \text {. } & 6\end{array}$

Castle Tomen _. $\quad \ldots \quad 4,34$

Causeways $\quad \ldots \quad 4,5,13,16,24$

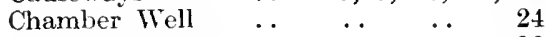

Chantry, Perrystone .. .. 33

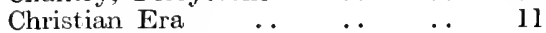

Churchdown (G.) $\quad$. $\quad \ldots, \quad \ldots, \quad 22$

Churches-6, 7, 11, 12, 18, 19, 20, 21, 22, $24,25,26,28,29,33,34$

Cist

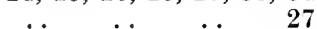

Clee Hill (S.) $\quad$.. $\quad \ldots . \quad \ldots 4,18$

$\begin{array}{llllll}\text { Clifford } & \ldots & \ldots & \ldots & \ldots & 6\end{array}$

$\begin{array}{llll}\text { Clyro Church (R.) } & \text {. } & \text {. } & 33\end{array}$

Codrington, Thos. $\quad \cdots \quad 15,25$

Colchester, Coleham, Coleridge .. 31

$\begin{array}{lllll}\text { Coldborough } & \ldots & \ldots & \ldots & 27\end{array}$

Cold Harbour, Coldridge ... .. 31

Coldman's Hill, Coldstone _. 31

Coldwell $\quad \ldots \quad$.. $\quad \ldots \quad$ 24, 31

Cole, Coleman $\quad . . \quad \ldots . \quad \ldots \quad 24,31$

Cole-prophet, Cold-prophet .. 31

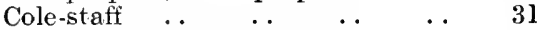

Coleshill, Colestock, Coleford .. 3 I

Colewelle, Colmanswell . . . . 31

Coles Tump, Coles Mountain .. 31

Coley, Colebury, Colebatch .. 31

$\begin{array}{llll}\text { Colva Church (R.) } & \text {. . } & \text {. } & 33\end{array}$

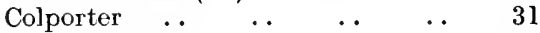

Colva Hill (R.) .. $\quad$.. $\quad$.. 32

Colwall $\quad \ldots \quad \ldots \quad \ldots \quad \ldots \quad 24,31$

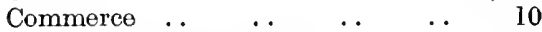

Concrete in Causeways .. $\quad$.. 44

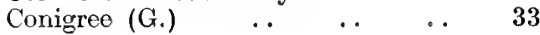

Constable's Firs $\quad$. $\quad$.. $\quad$.. 20

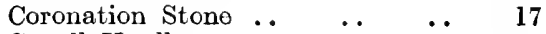

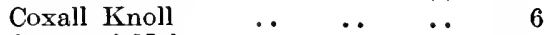

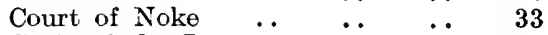

Craft of the Ley-men $\quad$.. $\quad$.. 30

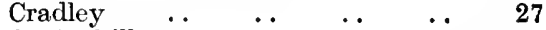

Credenhill $\quad . \quad \ldots \quad \ldots \quad \ldots \quad 5,17,33$

Croft Ambury $\quad \ldots \quad \ldots \quad 9,21,33$

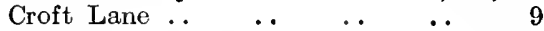

$\begin{array}{llllll}\text { Crosses } & \ldots & \ldots & \ldots & \ldots & 5,17\end{array}$

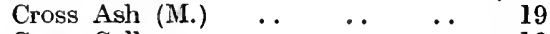

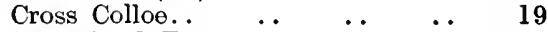

Cross End Farm .. $\quad \ldots \quad \ldots 6,33$

Cross in Hand $\quad . . \quad \ldots . \quad 14,33$

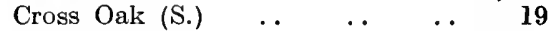

Cross Roads $\quad$. . $\quad$. . $\quad 11,13$

Cross of the Tree .. $\quad \ldots \quad \ldots 19,28$

Cruger Castle (R) $\quad \ldots \quad$.

$\begin{array}{llllll}\text { Cullis } & \ldots & \ldots & \ldots & \ldots & 15\end{array}$

$\begin{array}{llllll}\text { Cusop } & \ldots & \ldots & \ldots & \ldots & 12\end{array}$

$\begin{array}{llllll}\text { Cuttings } & \ldots & \ldots & \ldots & \ldots & 15\end{array}$

D, intrusion of letter $\quad \ldots \quad \ldots \quad 27$

Dancing in Circle .. $\quad . . \quad \ldots . \quad 14$

Dartmoor .. $\quad \ldots \quad \ldots \quad \ldots \quad 18,25$

Deerfold Forest .. $\quad$. $\quad \ldots \quad \ldots \quad 28$

Duchess Walk (S.). . . . $\quad$. 20

$\begin{array}{llll}\text { Dial Carreg (M.) } & \text {. } & \ldots & 18\end{array}$

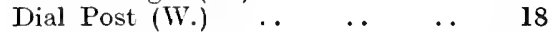

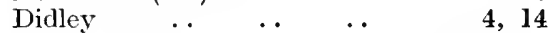

Dinedor Camp $\quad . \quad \ldots \quad$ ]2, 21, 30

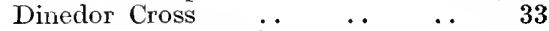

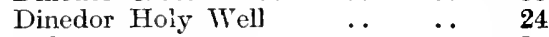

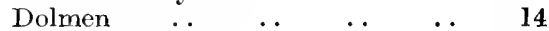

Domestic Camp . . $\quad$. . $\quad$.. 20

Doomsday Book . . $\quad$. . $\quad \ldots .22$

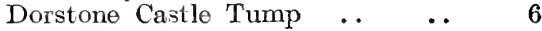

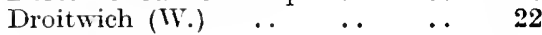

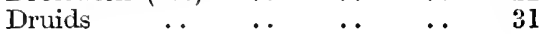

$\begin{array}{lllll}\text { Eardisland .. } & \ldots & \ldots & \ldots & 14\end{array}$

Eardisley Park . . . . . 23

Earthworks . . 10, 11, 14, 15. 20, 21, 22, 23

Eastwood Oak .. . . $\quad 5,19$

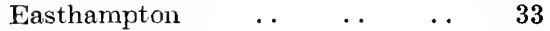

Eaton Bishop Camp $\quad$. $\quad \ldots \quad 33$

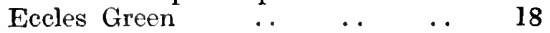

$\begin{array}{llllll}\text { Elsdon } & \ldots & \ldots & \ldots & \ldots & 33\end{array}$

$\begin{array}{lllll}\text { Enclosures } & \ldots & \ldots & \ldots & 9\end{array}$

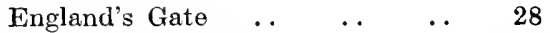

Ermin Street (G.) . . . . $\quad$.. 33

Exeter, church over ley .. $\quad$.. 22

Evolution of Moats $\quad . .4 \quad 4,10,15$

Evolution of Mounds .. 4,14

Evolution of Crosses $\quad . \quad$ 5, 11 
Felin-fach Moat (B.) $\quad$. $\quad$.. $\quad 6$

Ferries $\quad \ldots \quad \ldots \quad \ldots \quad 12,18,23$

Field Work $\quad . \quad \ldots \quad 32,33,34$

Fine Street and Finsbury $\quad$. 29

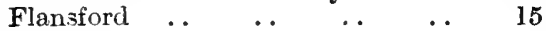

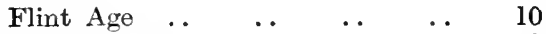

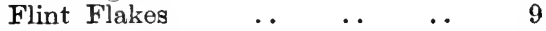

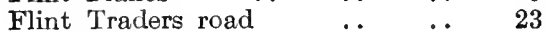

Folly, The (R.) .. $\quad$.. $\quad$.. 18

Folk-mote $\quad$. $\quad \ldots \quad \ldots, \quad \ldots \quad 14$

Fords $-4,5,6,12,13,15,17,29,30,33$

Forest $\quad . \quad \ldots \quad \ldots . \quad 20,25$

Foss (Glos. and Wilts.) .. ..

Four Stones (R.) $\quad \ldots \quad 4,18,3$

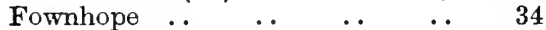

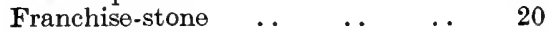

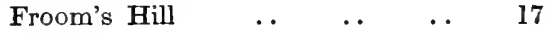

Gallows Tump _. $\quad \ldots \quad \ldots .23$

$\begin{array}{llllll}\text { Garn } & \text {. } & \text {. } & \ldots & \ldots & 10\end{array}$

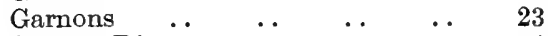

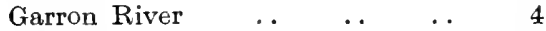

$\begin{array}{llllll}\text { Gate } & \ldots & \ldots & \ldots & \ldots & 28\end{array}$

$\begin{array}{lllll}\text { Gatley } & \ldots & \ldots & \ldots & 15,28\end{array}$

$\begin{array}{llllll}\text { Gatsford } & \ldots & \ldots & \ldots & \ldots & 28\end{array}$

Gillespie, Mrs. $\quad \ldots \quad$. $\quad \ldots \quad 27$

$\begin{array}{lllll}\text { Gillow } & \ldots & \ldots & \ldots & 6,16\end{array}$

$\begin{array}{lllllr}\text { Giraldus } & \ldots & \ldots & \ldots & & 4,17 \\ \text { Glade } & \ldots & \ldots & \ldots & \ldots & 12\end{array}$

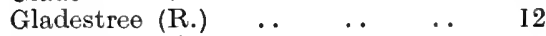

$\begin{array}{llll}\text { Glascwm Hill (R.) } & \text {. } & \ldots & 6\end{array}$

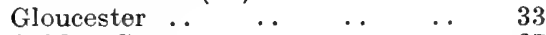

$\begin{array}{lllll}\text { Golden Cross } & \text {. } & \ldots & \ldots & 27\end{array}$

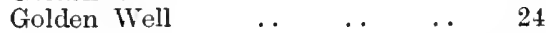

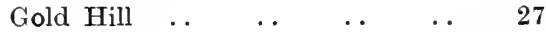

Gold Post .. $\quad \ldots \quad \ldots \quad \ldots 24,27$

Gold Traders road $\quad \ldots \quad \ldots 24,27$

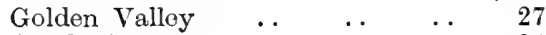

$\begin{array}{llllll}\text { Goodrich } & . & \ldots & \ldots & \ldots & 24\end{array}$

Gospel Oaks $\quad \ldots \quad \ldots \quad \ldots \quad 11,19$

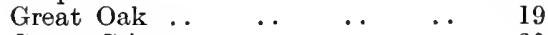

$\begin{array}{lllll}\text { Green Crise } & \ldots & \ldots & \ldots & 20\end{array}$

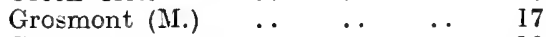

$\begin{array}{llllll}\text { Grove } & . & \ldots & \ldots & \ldots & 19\end{array}$

Gwaun ceste Hill (R.) . . . 33

Hampstead Heath (Mid.) .. 20

Hargest Ridge $\quad$. $\quad \ldots \quad \ldots \quad \ldots \quad 16$

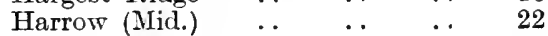

Harpton Court (R.) $\quad$. . $\quad$.. $\quad 20$

Hatterill Hill $\ldots$.. $\quad$.. 25

$\begin{array}{lllll}\text { Hay Tump } & \ldots & \ldots & \ldots & 6\end{array}$

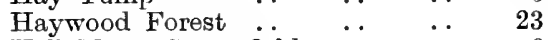

Hell Moat, Sarnesfield .. $\quad$. . 64

Hentland Cross .. $\quad$.. $\quad$.. $\quad 17$

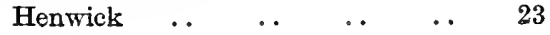

Hereford $\quad \ldots \quad \ldots \quad 5,20,23,29$

- All Saints .. $\quad . \quad 12,21,22$

— Barrol Street .. .. 24

— Bishop's Meadow .. $\quad$.. 23

$\begin{array}{llll}\text { — Broad Street } & \ldots & \ldots & 22\end{array}$

- Chapel of Hospitallers .. 24

- Cathedral .. 4, 12, I6, 21, 22

$\begin{array}{lll}- \text { Castle Hill ... } & \ldots & 21,23 \\ \end{array}$

— Church Street .. $\quad$. 28

— Harley Court $\quad$.. $\quad$.. $\quad 16$

— The Knoll .. $\quad$. . $\quad$.. 23

- Offa Street $\ldots \quad \ldots \quad \ldots \quad 12,22$

\begin{tabular}{lllll} 
Overbury & $\ldots$ & $\ldots$ & $\ldots$ & 23 \\
\hline
\end{tabular}

$\begin{array}{lllll}\text { — Prospect } & \text {. } & \text {. } & \text {.. } & 34\end{array}$

— St. John Street .. $\quad$. 24

— St. Peter's .. $\quad \ldots \quad$.. 22

— Quay Street N .. . 24

— Venn's Lane $\quad$. . . . $\quad 34$

— Wye Street.. $\quad$. $\quad \ldots \quad 17$

Herefordshire Beacon .. $\quad 6,21$

Herrock Hill, Holy Well _. 24

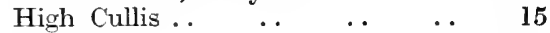

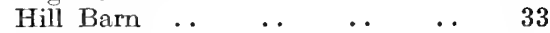

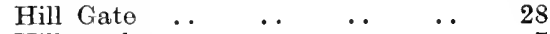

$\begin{array}{lllll}\text { Hill-tracks } & \ldots & \ldots & \ldots & 7\end{array}$

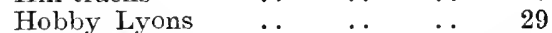

Hoggs Mount $\quad \ldots \quad 5,21,22,23,24$

Holme Lacy House . . . 33

Holmer $\quad . \quad 5,6,16,19,24,33,34$

Holmer Tumps $\quad . \quad 5,23,24,34$

Hom Green Cross . . . 30

Homesteads $\quad \ldots \quad 4, \ddot{11}, 2 \ddot{2}, 26,27$

Holy Wells .. $\quad . . \quad \ldots \quad 6,24$

Hope-under-Dinmore $\quad$. $\quad \ldots \quad 18$

Houghton Mound .. $\quad$. $\quad \ldots \quad 4$

How Caple Church $\quad \ldots . \quad \ldots .34$

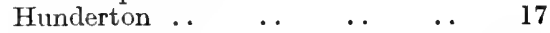

Hungerstone $\quad \ldots \quad \ldots \quad$ 14, 15

Hungerford (Mid.) _. . $\quad$ I5

Implements for mapping _ . $\quad 32$

Ingestone $\ldots \quad \ldots \quad \ldots \quad \ldots, 13$

Iron $\quad \ldots \quad \ldots \quad \ldots \quad \ldots 16,23$

Irfon Valley (B.) $\quad$. . $\quad \ldots .34$

Island on moat $\quad . \quad \ldots \quad \ldots \quad 15, \mathrm{I} 6$

Ivington Bury $\quad \ldots \quad \ldots . \quad \ldots \quad 27$

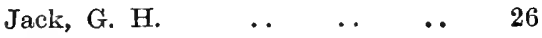

Kenchester .. $\quad \ldots \quad \ldots \quad$ 18, 19, 26

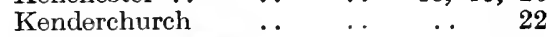

Kiln Ground Wood . . . 23

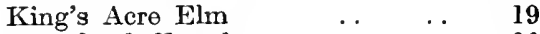

$\begin{array}{llll}\text { Kingsland Church } & \ldots & \ldots & 26\end{array}$ 


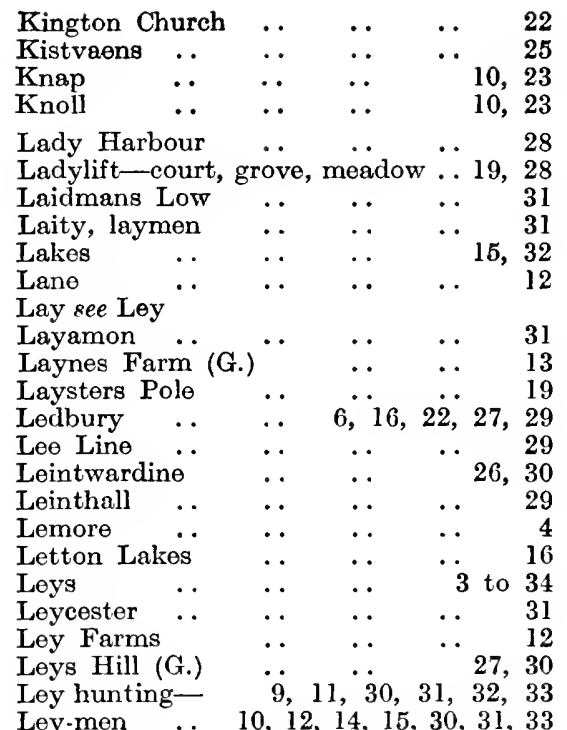

Leys, route of $-6,10,11,12,13,20,22$, $23,24,25,26,29,30,33,34$

Lidyatt $\quad \ldots \quad$. $\quad \ldots \quad$.. 28

Linton $\quad \ldots \quad \ldots \quad \ldots \quad \ldots 29,34$

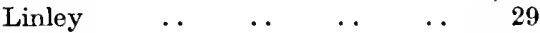

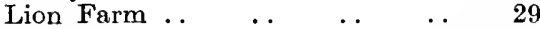

Litley $\quad \ldots \quad \ldots \quad \quad \ldots \quad 17,20,24,29$

Little Hereford . . $\quad$. $\quad \ldots \quad 29$

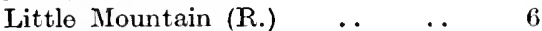

— (Westbrook).. $\quad$.. $\quad$. 33

Llanelieu Church (B.) $\quad$. $\quad$. . 64

Llanigon (B.) $\quad \ldots \quad \ldots . \quad \ldots \quad 5$

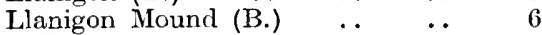

Llansaintfraed-in-Elvel (B.) $\quad$.. 18

Llanthony (Mon.) . . $\quad$.. $\quad$. $\quad 5$

Llanthony (Glos.) .. $\quad$. . $\quad$. $\quad 33$

Llanvihangel Court (M.) _. 20

Llanvihangel Crucorney (M.) _. 4, 15

Llanvihangel-nant-Melan (M.) $\quad$.. 18

Llowes Church (R.) .. . . 33

Longtown .. $4,5,13,15,20,25$

Longford . . $\quad \ldots \quad$. . $\quad \ldots \quad 30$

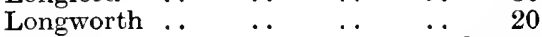

$\begin{array}{lllll}\text { Low } & \ldots & \ldots & \ldots & 10,27,31\end{array}$

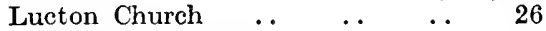

Ludgate Hill, London . . $\quad$. $\quad 22$

$\begin{array}{lllll}\text { Ludlow (S.) } & \text {. . } & \text {. . } & \text {. . } & 27\end{array}$

$\begin{array}{lllll}\text { Lugg Bridge } & \ldots & \ldots & \ldots & 26\end{array}$

Lyde Cross Tree $\quad . . \quad \ldots \quad \ldots \quad \ldots \quad 19$

$\begin{array}{llllll}\text { Lyepole } & \ldots & \ldots & \ldots & \ldots & 19\end{array}$
Lyonshall, Lynhales _. $\quad$. $\quad 29$

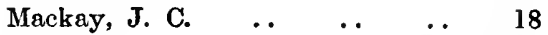

Madley $\quad \ldots \quad \ldots . \quad \ldots \quad 5,17,22$

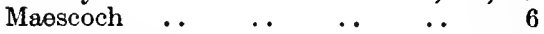

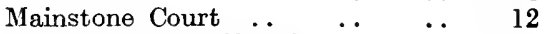

Malvern Priory Church .. 6,33

Malvern Hills $\quad \ldots \quad 6,12,15,23,24$

$\begin{array}{llllll}\text { Magna } & \ldots & \ldots & \ldots & \ldots & 18\end{array}$

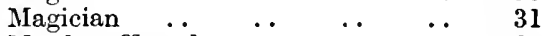

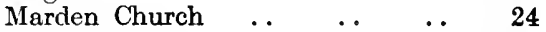

Marstow .. .. $\ldots, 4,15$

Mark Stones-5, 10, 16, 17, 18, 21, 23, 24

Mathon Church $\quad$. $\quad$.. $\quad$.. 33

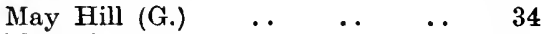

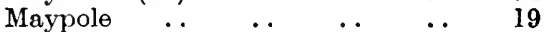

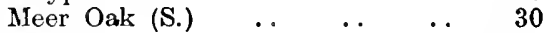

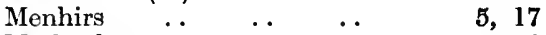

$\begin{array}{llllll}\text { Merbach } & \ldots & \ldots & \ldots & \ldots & 6\end{array}$

Merry Hill .. $\quad . . \quad \ldots \quad \quad$ 14, 23

Michaelchurch Escley $\quad \ldots \quad 6,33$

Milton $\quad \ldots, \ldots, \quad \ldots, \quad \ldots \quad 33$

Moats-4, 6, $7,10,11,14,15,16,24,33$

Noccas $\quad \ldots \quad \ldots \quad \ldots \quad 6,22,33$

Monnington Walks $\quad \ldots \quad 5,6,19,33$

Monnington Church $\quad \ldots \quad 6,33$

Monnow $\quad \ldots \quad$.

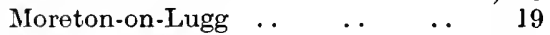

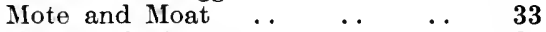

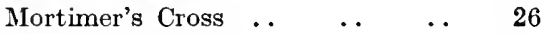

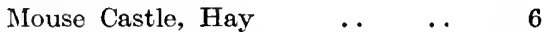

Mouse Castle, Hereford . . . . 23

Mounds-4, 6, 7, 10, 11, 12, 14, 19, 20, $21,22,23,24,25,26,27,28,29$, $30,31,32,33,34$

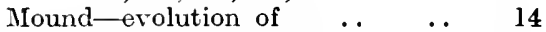

Mound (various names for)

Mountain Tracks .. $\quad \ldots \quad \ldots \quad 5,12$

Mynydd-Brith Tump _. $\quad$. . 66

Mynydd Ferddin Hill (B.) .. 23

$\begin{array}{lllll}\text { Mullhampton } & \ldots & \ldots & \ldots & 33\end{array}$

Neolithic Age $\quad \ldots \quad \ldots \quad \ldots \quad 10,13$

Newchurch Hill (R.) _. $\quad$. 23

New End .. $\quad \ldots \quad$.. $\quad \ldots \quad 29$

New Radnor Castle (R.) $\quad$.. 20

North Hill Malvern .. .. 33

$\begin{array}{llll}\text { Notches-sighting } & \ldots & 4,15\end{array}$

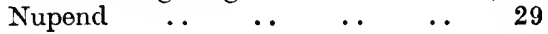

Oaks $\quad \ldots \quad \ldots \quad \ldots \quad b, 11,19$

Oakley Park (S.) $\quad \ldots \quad \ldots, 20$

Olchon $\quad \ldots \quad \ldots \quad r \quad 5,12,13,28$

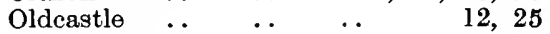

Old Gore Cross $\quad . . \quad \ldots \quad \ldots \quad \ldots \quad 34$

Old Radnor Church $\quad$.. $\quad$.. 20 


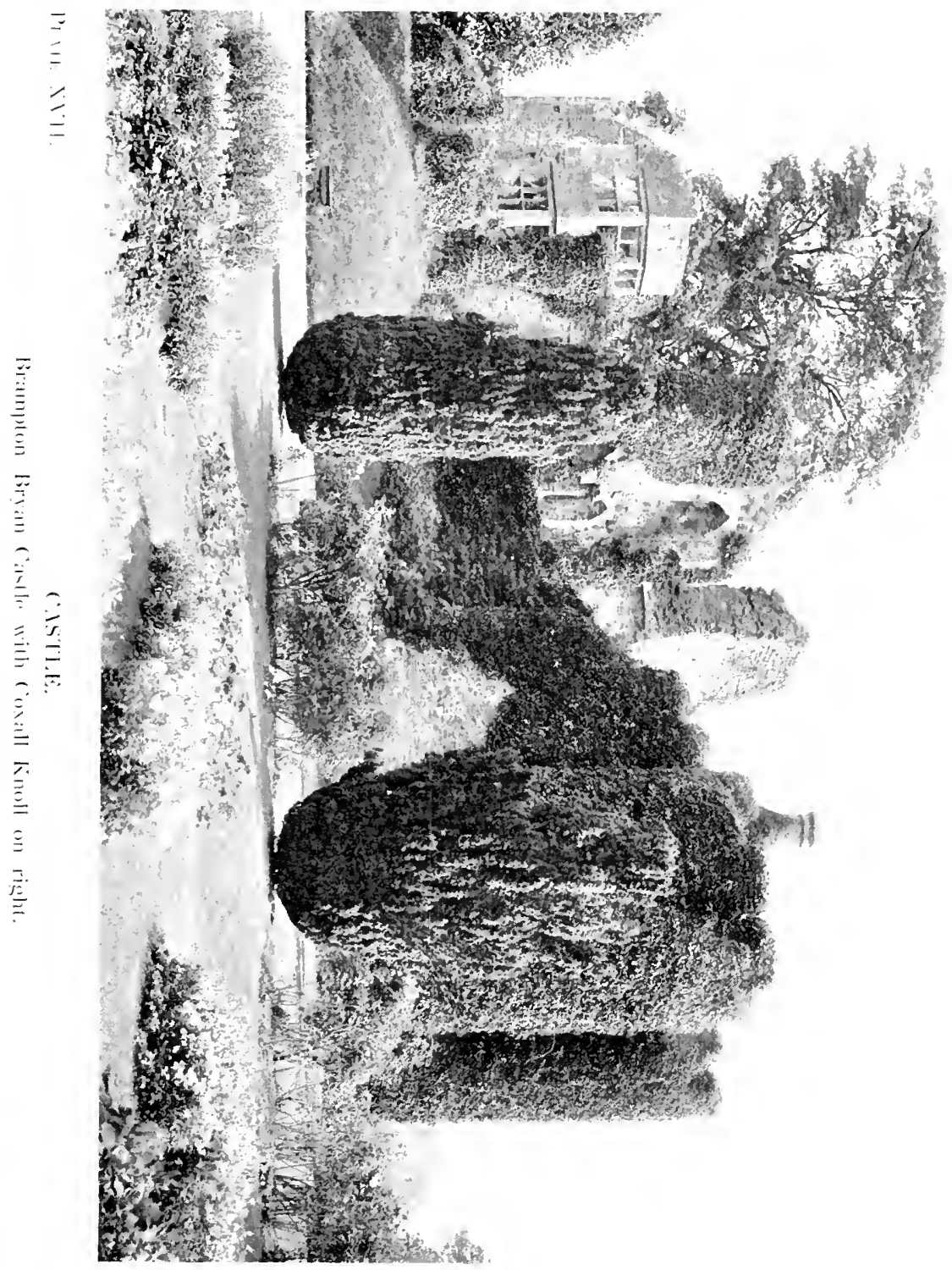




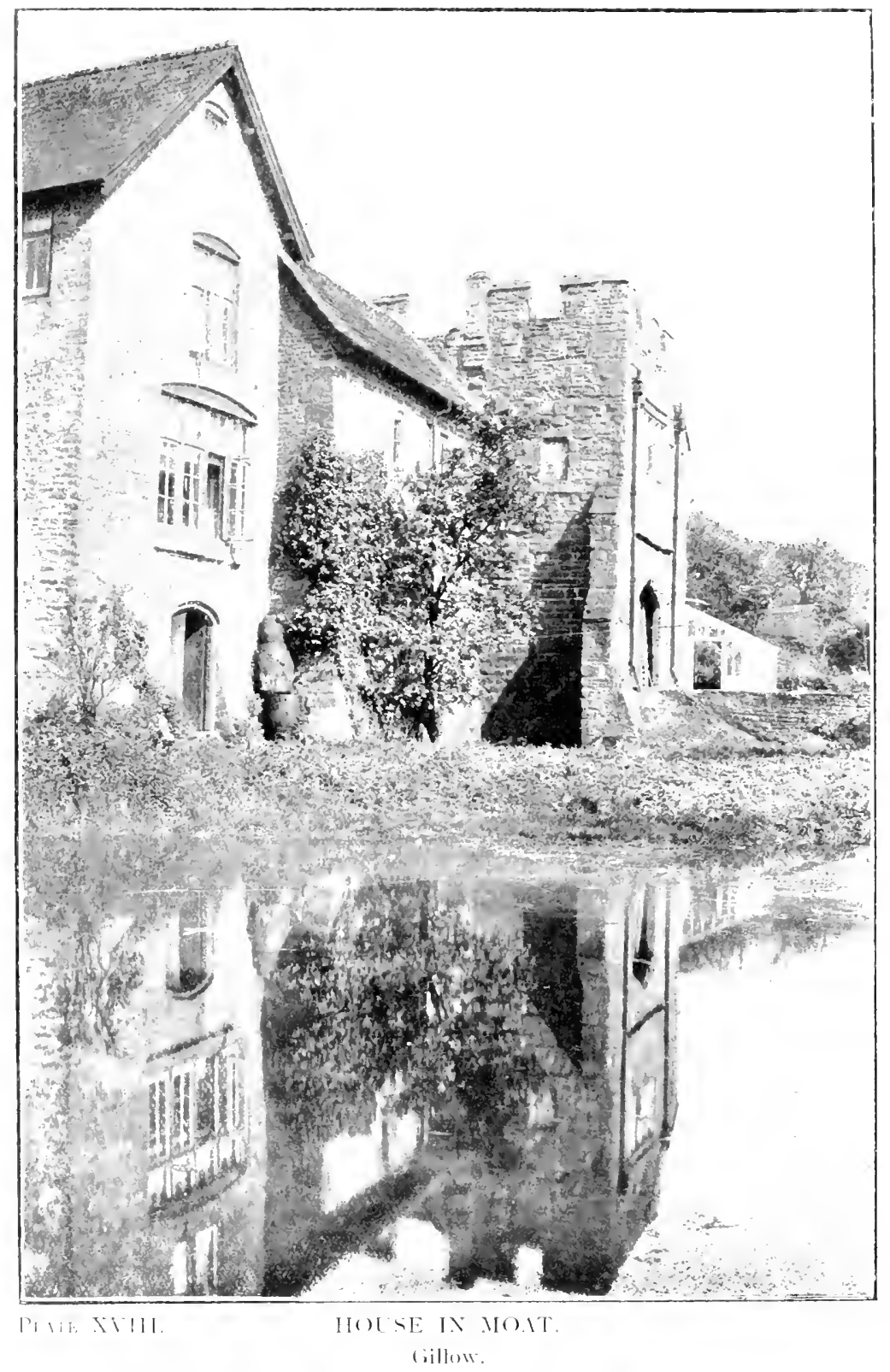


One Tree Hill

Ordnance Maps

Over Ross

$\begin{array}{lllr}\ldots & \ldots & 5,19 \\ \ldots & \ldots & & 11,32 \\ . & & \ldots & 19\end{array}$

Pains Castle Mound

(R.)

. 6

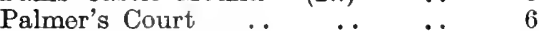

Palace Ford, Hereford .. .. 30

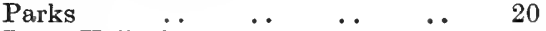

Park Hall (S.) .. $\quad$.. $\quad$.. 4

Parallel Roads .. $\quad$.. $\quad$.. 12

$\begin{array}{lllll}\text { Partricio (1.) } & \text {. } & \text {.. } & \text {. } & 17\end{array}$

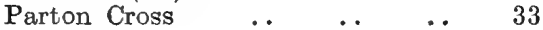

$\begin{array}{llllll}\text { Paytoe } & \text {. } & \ldots & \ldots & \ldots & 26\end{array}$

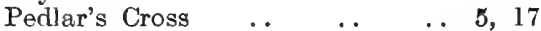

Pen-y-Beacon $\quad \ldots \quad 4,6,24,33$

Perry Hill .. $\quad$. $\quad$. . $\quad$. 33

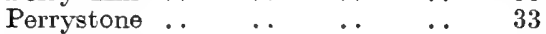

$\begin{array}{llllll}\text { Philology } & \ldots & \ldots & \ldots & \ldots & 26\end{array}$

$\begin{array}{lllll}\text { Picts Cruss } & \ldots & \ldots & \ldots & 30\end{array}$

Pilgrim's Way, Kent $\quad \ldots \quad \cdots 13,25$

Pilgrim's Staff $\quad . \quad \ldots \quad \ldots \quad \ldots 28$

Pine (Scotch or Scots) .. $\quad$.. 20

Piper, G. H. $\quad$. $\quad$.. $\quad$. 25

Pipe and Lyde Church .. $\quad . .33$

Ponds $\quad \ldots 4,5,10,11,13,14,16,32$

Portcullis $\quad . \quad \ldots \quad \ldots \quad \ldots \quad \ldots, 15$

Pottery, Ancient .. $\quad . \quad \quad 5,6,23$

Precipice Walk .. $\quad$.. $\quad \ldots, \quad 12$

Preston-on-Wye Church $\quad$.. 6

Preston Wynne .. .. $\quad$ 15, 29

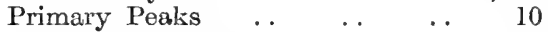

Priory Wood, Clifford .. . . 6

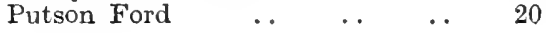

$\begin{array}{lllll}\text { Queen's Stone } & \ldots & \ldots & \ldots & 17\end{array}$

Radnor Forest . . . . $\quad 4,34$

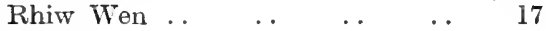

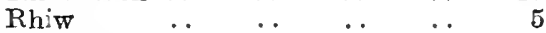

Rhos-goch Castle Tump (R.) $\quad$.. 6

Redborough (R.) .. $\quad$.. $\quad$. 23

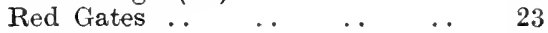

Red Hill $\quad$. $\quad \ldots \quad$. . $\quad \ldots \quad 33$

$\begin{array}{lllll}\text { Red House } & \text {. } & \text {. . } & \text {. } & 23\end{array}$

Red Ley $\quad . \quad \ldots . \quad \ldots \quad$ 12, 23

$\begin{array}{lllll}\text { Red Lion } & . & \ldots & \ldots & 5,17\end{array}$

Red Pottery $\quad \ldots \quad \ldots \quad \quad \ldots \quad 5,6,16$

Red Traders road .. $\quad \ldots \quad 5,6,23$

Red Wych End .. $\quad$.. $\quad$.. 29

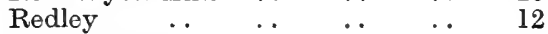

$\begin{array}{lllll}\text { Ridge-ways .. } & \ldots & \ldots & \ldots & 7\end{array}$

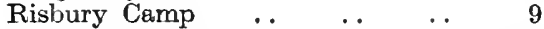

Roman Stations $\quad . \quad \ldots \quad 9,18,26$

Roman Surveyors .. 15, 18, 20, 21, 26

Roman Roads .. 9, 10, 13, 16, 25, 26

Roofing Tile.stones .. .. 5
Rosemary Topping (G.) $\quad$.. $\quad 29$

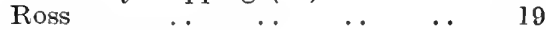

Rudford Church (G.) $\quad$. $\quad \ldots .33$

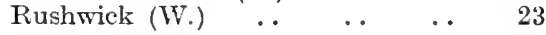

$\begin{array}{llllll}\text { Salt } & \ldots & \ldots & \ldots & \ldots & 22\end{array}$

Symonds Yat $\quad \ldots \quad$.

Saltways $\quad \ldots \quad \ldots . \quad \ldots \quad 9,22,23$

$\begin{array}{llll}\text { Saltmarshe Castle } & \ldots & \ldots & 23\end{array}$

$\begin{array}{llll}\text { Sarnesfield Moat .. } & \ldots & \ldots & 6\end{array}$

Scotch (or Scot3) Fir $\quad \ldots \quad$ 5, 19, 20

Scots Hole .. $\quad$. . . . $\quad$.. 23

$\begin{array}{lllll}\text { Shrewsbury .. } & \ldots & \ldots & \ldots & 22\end{array}$

Shucknell Hill .. $\quad \ldots \quad 6,33$

$\begin{array}{llllll}\text { Shelwick } & \ldots & \ldots & \ldots & \ldots & 14\end{array}$

$\begin{array}{llll}\text { Sighting Columns .. } & \ldots & \ldots & 21\end{array}$

Sighting Cuttings .. $\quad \ldots \quad 4$, 15

Sighting Methods .. $\quad \ldots \quad 9$ to 34

Sights, rifle .. $\quad$. $\quad \ldots, \quad \ldots, \quad 9$

Sighting Stones $\quad \ldots 4,5,6,11,17,18,21$

Silbury (Wilts.) $\quad$. $\quad \ldots \quad \ldots .25$

$\begin{array}{lllll}\text { Silver Tump } & \text {. } & \text {. } & \text {. } & 28\end{array}$

Sites and Sighting-11, 14, 16, 21, 22, 24

Skirrid (M.) $\quad . \quad \ldots \quad \ldots \quad 4,25$

Slwch Camp (B.) .. $\quad \ldots . \quad \ldots \quad 33$

$\begin{array}{lllll}\text { Snodhill Castle } & \ldots & \ldots & \ldots & 25\end{array}$

$\begin{array}{lllll}\text { Soothsayers } & \ldots & \ldots & \ldots & 31\end{array}$

Speech House (G.). . $\quad$. $\quad \ldots .30$

St. Ann's Well (W.) $\quad$. $\quad 6,24,33$

St. Clement Danes, London $\quad . \quad 22$

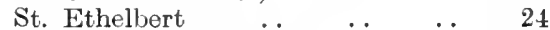

St. Guthlac Church _. $\quad$. 24

St. Ishaw's Well (M.) $\quad$. $\quad \ldots . \quad 17$

St. Martin's in the Fields $\quad . .22$

St. Mary le Strand _. $\quad$. 22

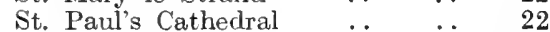

St. Pewtress Well .. $\quad$. $\quad \ldots .24$

St. Tecla's Chapel (G.) $\quad$. $\quad$. 22

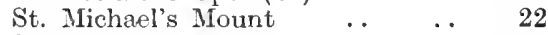

Stanbatch, Stanbury $\quad \ldots \quad$. 28

Stanton, Stanley, Stanwell $\quad$. 28

$\begin{array}{lllll}\text { Stock } & \ldots & \ldots & \ldots & 14,19\end{array}$

$\begin{array}{lllll}\text { Stroke Prior } & \ldots & \ldots & \ldots & 18\end{array}$

$\begin{array}{llllll}\text { Storridge } & \ldots & \ldots & \ldots & \ldots & 23\end{array}$

Stone Rows $\quad \ldots \quad$. . $\quad \ldots \quad 25$

$\begin{array}{lllll}\text { Street Court } & \ldots & \ldots & \ldots & 30\end{array}$

$\begin{array}{lllll}\text { Stretford Church } & \ldots & \ldots & \ldots & 30\end{array}$

Stretton Grandison $\quad$. $\quad 9,33$

$\begin{array}{llllll}\text { Suffix } & \ldots & \ldots & \ldots & \ldots & 27\end{array}$

$\begin{array}{lllll}\text { Sugwas Park } & \ldots & \ldots & \ldots & 33\end{array}$

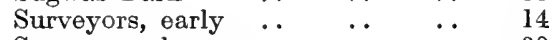

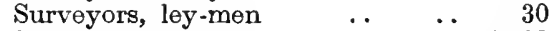

Surveyors, Roman $\quad$. $\quad 15,21$

$\begin{array}{lllll}\text { Sutton Lakes } & \ldots & \ldots & \ldots & 16\end{array}$

Sutton Walls $\quad \ldots \quad \ldots \quad \ldots, \quad \ldots, 18,20$ 


\begin{tabular}{|c|c|c|c|c|c|c|c|c|c|}
\hline Talgarth Church & (B.) & $\cdots$ & $\cdots$ & 6 & Water Gate (Inigo & Jon & es') & $\cdots$ & 15 \\
\hline Tan House & . & . & . & 13 & Watling Street, Lor & ndon & . & . & 22 \\
\hline Tarrington .. & .. & .. & . & 5 & Webtree & . & . & $\cdots$ & 28 \\
\hline Tenbury (W.) & . & . & . & 24 & Webton & . & . & . & 28 \\
\hline Ten Houses & . & . & . & 4 & Wellington .. & $\ldots$ & . & & 19 \\
\hline Terminal Hills & . & .. & 10,11 , & 21 & Wells-6, 10,11 , & 24,2 & 5,28 , & 30,31 , & 33 \\
\hline Three Elms & . & - & 19 & 24 & Weobley $\quad$. & . & . & 6,22 & 24 \\
\hline Three Gates & . & $\cdots$ & . & 28 & Weobley, Ash and & Cros & s.. & $\because$ & 28 \\
\hline Thruxton & & . & . & 15 & Wergin's Stone & . & . & 5,17 , & 18 \\
\hline Timber Line Wo & od & .. & . & 29 & Wheolbarrow Castl & & $\ldots$ & .. & 27 \\
\hline Tibberton Court & (G.) & . & . & 33 & Whitcliffe & . & . & . & 23 \\
\hline Tin Hill . . & $\ldots$ & . & . & 23 & Whitfield .. & . & . & . & 23 \\
\hline Tin Traders road & d .. & & . & 23 & Whitney, pottery a & & .. & 5,6 , & 23 \\
\hline 'Tinkers Hill and & Cross & (W.) & . & 23 & Whitman's Wood & . & .. & $\ldots$ & 23 \\
\hline Titterstone Clee & Hill (S & & & 4 & Whitwick Manor & . & . & . & 22 \\
\hline Tomen $\quad .$. & $\ldots$ & .. & 4 , & 10 & Whitecastle (M.) & .. & .. & . & 23 \\
\hline 'Totnor, Tothill, ? & Toot & .. & .. & 29 & White Cross & . & .. & . & 23 \\
\hline Totmans Low (D & Derby) & .. & $\ldots$ & 31 & White House & . & . & . & 22 \\
\hline Totteridge, Totte & enham & & .. & 29 & White Rocks & .. & $\ldots$ & $\ldots$ & 23 \\
\hline Traders' roads-9 & $9, \quad 10$, & 17 & $\begin{array}{l}22,23 \\
27,28,\end{array}$ & $\begin{array}{r}24, \\
29\end{array}$ & $\begin{array}{l}\text { White Stone } \\
\text { White Traders' roa }\end{array}$ & & $\ddot{m}$ & $\begin{array}{c}17,22, \\
\ldots\end{array}$ & $\begin{array}{l}33 \\
23\end{array}$ \\
\hline Trees $\quad \ldots$ & & 5,10 , & 12,19 & 20 & Whiteway Head & . & .. & .. & 23 \\
\hline Tre-fedw Mound & (M.) & .. & 4 & 14 & Whitewell House & .. & . & .. & 23 \\
\hline lrewyn House (1 & Mi.) & . & 20 & 27 & Whetstone & $\ldots$ & . & .. & 16 \\
\hline Trewyn Camp (M & & .. & 4 & 15 & Wiek (WV.) .. & . & $\ldots$ & $\ldots$ & 22 \\
\hline Triangular Wood & ds .. & .. & .. & 12 & Widemarsh & . & . & .. & 24 \\
\hline Tumps $-6,10,12$ & 2,14 & 15,20 , & 21,22 , & 23, & Wigmore $\quad$. & . & - & 6,22 , & 26 \\
\hline & & 25,27 , & 31,33 , & 34 & Wilton Castle & . & . & . & 19 \\
\hline Tumpa (B.) & . & .. & . & 6 & Winchester .. & . & . & .. & 25 \\
\hline Tumpy Lakes & .. & . & - & 16 & Wind's Point & . & $\cdots$ & $\cdots$ & 6 \\
\hline Tumpey Ley & .. & . & .. & 12 & Winforton $\ldots$ & $\ldots$ & . & . & 19 \\
\hline Tumulus $\quad$. & . & .. & .. & 10 & Winslow, Winsley, & Win & vard & $\ldots$ & 29 \\
\hline Tupsley .. & . & . & . & 34 & IVitcombe Park (G & & .. & . & 33 \\
\hline Turnaston $\ldots$ & $\ldots$ & . & . & 17 & Witches $\quad$. & . & . & .. & 31 \\
\hline Turrett Tump & .. & $\ldots$ & $\ldots$ & 6 & Withington & . & .. & .. & 15 \\
\hline Twt, Tooting & . & & 10 & 29 & Withington Lakes & $\cdots$ & . & . & 16 \\
\hline & & & & & Wood, Jas. G. & . & . & . 25, & 29 \\
\hline Upperton $\quad \ldots$ & .. & $\cdots$ & $\cdots$ & 18 & Woodyatts Cross & . & . & $\ldots$ & 28 \\
\hline Upton (Bishop) C & Court & . & . & 33 & Woolhope Church & & $\cdots$ & . & 23 \\
\hline Urishay Castle & . & . & . & 25 & Wormelow Tump & . & . & . & 27 \\
\hline & & & & & Worsell , & . & $\cdots$ & . & \\
\hline Vowchurch Cros3 & & . & 5 , & 17 & Wyaston Leys & $\cdots$ & $\cdots$ & $\ddot{14} 23$ & 12 \\
\hline Walmer Street & $\cdots$ & $\cdots$ & $\ldots$ & 24 & $\begin{array}{l}\text { Wych } \\
\text { Wye }\end{array}$ & $\cdots$ & $\ldots$ & 14, 26, & 34 \\
\hline Walmsley .. & .. & .. & . & 24 & Wye Street.. & . & . & $\ldots$ & 5 \\
\hline Walm's Well & . & $\cdots$ & $\cdots$ & 24 & & & & & \\
\hline Walford Church & $\cdots$ & $\ldots$ & .. & 30 & Yarkhill .. & & .. & . & 16 \\
\hline Walton (R.) & . & . & .. & 18 & Y-Fan-Drongarth & (B.) & . & . & 33 \\
\hline Walsopthorne & .. & . & . & 6 & Yarpole $\quad .$. & $\ldots$ & . & . & 19 \\
\hline Warden The (R.) & .. & .. & . & 34 & Yat & $\ldots$ & $\ldots$ & . & 28 \\
\hline Warslow .. & . & . & .. & 27 & Yatton & .. & . & .. 28, & 33 \\
\hline Warwick, Chepel & over & & -. & 22 & & & & & \\
\hline
\end{tabular}




\section{ACKNOWLEDGMENTS.}

Six of the photographs are by Mr. W. M. McKaig, helper in many miles of ley-hunting.

This page is King 8 vo. in the Ideal series of paper sizes, wherein octavo and quarto have the same proportion, and three master sizes give a full series of uniform shape.

Hereford.

The letterpress printed by the "Hereford Times," Ltd., of

The half-tone blocks by Messrs. Emery Walker, Ltd., London, except six kindly lent by the Woolhope Club.

The illustrations and maps printed by Messrs. Ebenezer Baylis, Worcester.

The two-colour title by Mr. W. E. Henner, Hereford.

\section{INSTRUMENTS FOR LEY-MAPPING.}

Moveable head $T$ squares with divided quadrant, also other special appliances supplied if a demand arises.

\section{OTHER PUBLICATIONS.}

THE WATKINS IIANUAL of Photographic Exposure and Development. 9th Edition (about 80,000 sold).

"The only Manual I have read which seems to me absolutely simple and direct." - Westminster Gazette. (Post 3d.) 1s. 3d.

MUST WE TRADE IN TENTHS, being a plea against Decimal and for Octaval Coinage as more exactly fitting the wants and usage of all who make, grow, buy or sell things.

"A powerful plea."-Financier and Bullionist. (Post 1d.) 3d.

\section{TWO LEAFLETS FREE FOR POSTAGE.}

OCTAVAL NOTATION AND THE MEASUREMENT OF BINARY INCH FRACTIONS.

IDEAL PROPORTIONS AND SIZES FOR PRINTING PAPERS.

We were established in 1900 for the manufacture of Mr. Watkins's Exposure Meters and Development Aids in Photography. Also Dough Meters for household and trade bakers, and steel Octaval Rules.

As?: for Lisis.

WATKINS' METER CO., HEREFORD.

ADvT. 


. 


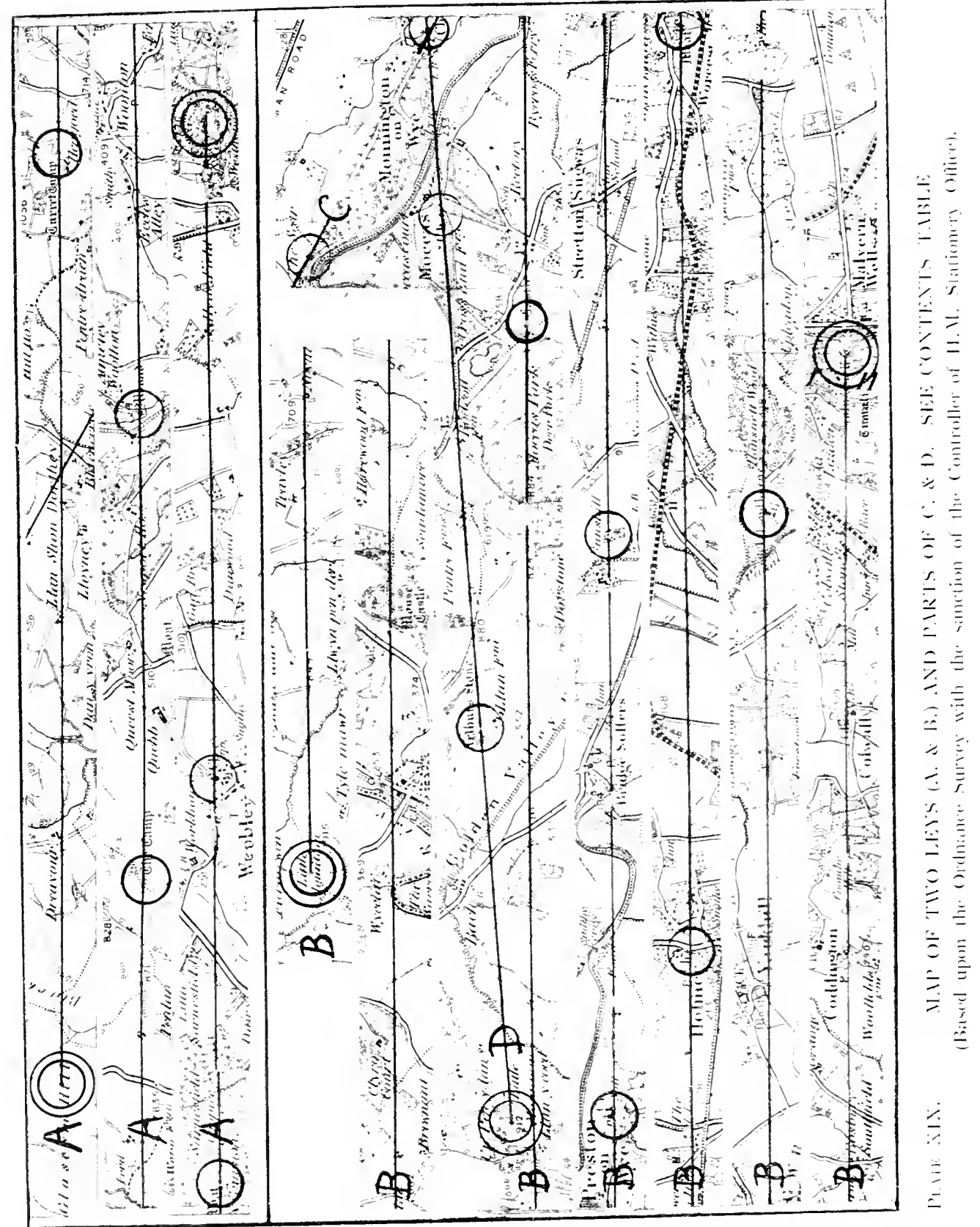




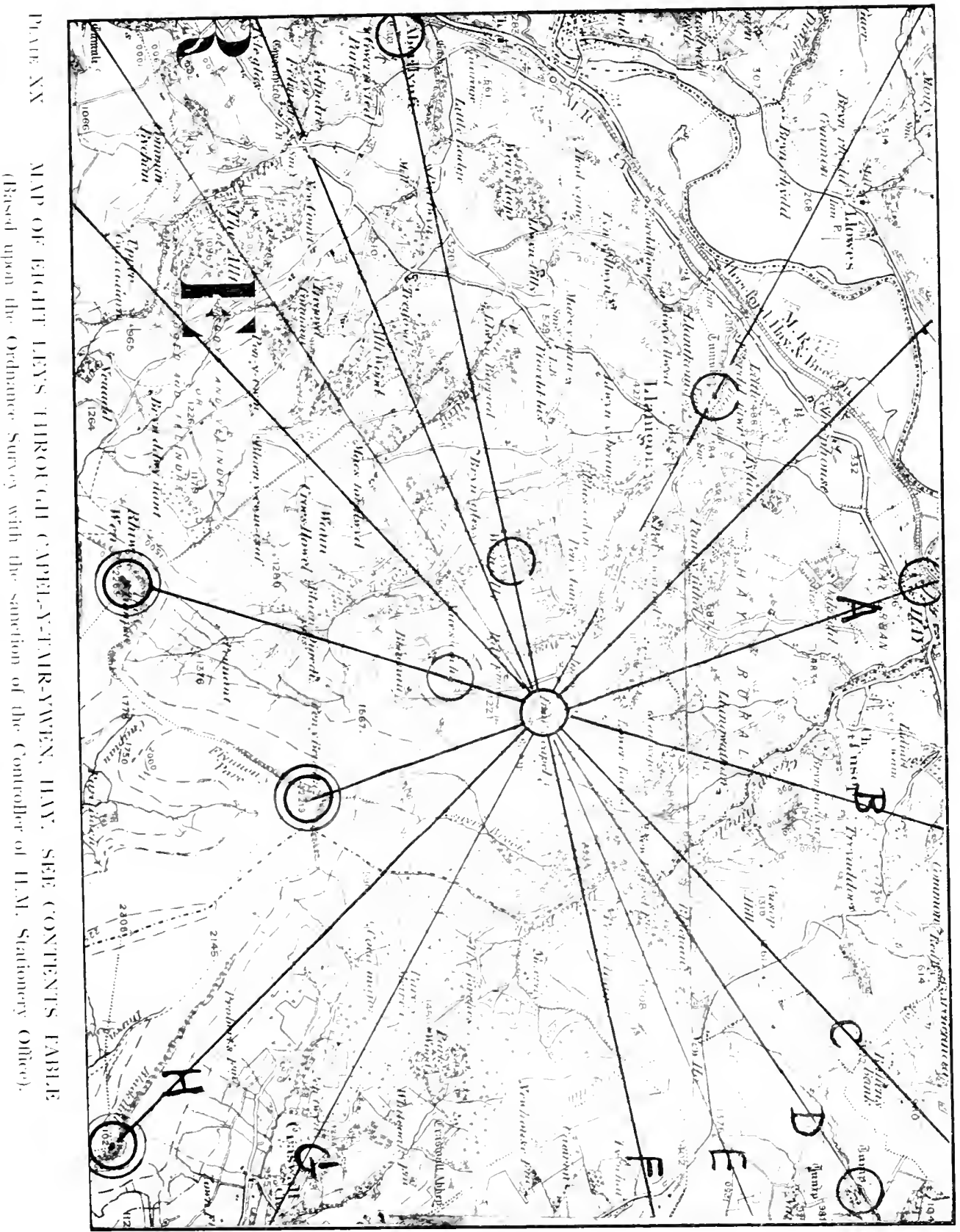



. 



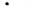


